\title{
geosciences
}

ISSN 2076-3263

www.mdpi.com/journal/geosciences

Article

\section{Identifying Sources and Assessing Potential Risk of Exposure to Heavy Metals and Hazardous Materials in Mining Areas: The Case Study of Panasqueira Mine (Central Portugal) as an Example}

Carla Candeias ${ }^{1, *}$, Eduardo Ferreira da Silva ${ }^{1}$, Paula F. Ávila ${ }^{2}$ and João Paulo Teixeira ${ }^{3}$

1 GeoBioTec - Geobiosciences, Geotechnologies e Geoengineering Research Center, Geosciences Department, University of Aveiro, Campus de Santiago, Aveiro 3810-193, Portugal;

E-Mail: eafsilva@ua.pt

2 LNEG - National Laboratory of Energy and Geology, Rua da Amieira, Apartado 1089, S. Mamede de Infesta 4466-901, Portugal; E-Mail: paula.avila@lneg.pt

3 Environmental Health Department, National Institute of Health, Rua Alexandre Herculano, 321, Porto 4000-055, Portugal; E-Mail: jpft12@gmail.com

* Author to whom correspondence should be addressed; E-Mail: candeias@ua.pt; Tel.: +351-968-337-915; Fax: +351-234-370-605.

External Editor: Jose A. Centeno

Received: 10 June 2014; in revised form: 15 September 2014 / Accepted: 17 September 2014 / Published: 26 September 2014

Abstract: The Sn-W Panasqueira mine, in activity since the mid-1890s, is one of the most important economic deposits in the world. Arsenopyrite is the main mineral present as well as rejected waste sulphide. The long history is testified by the presence of a huge amount of tailings, which release considerable quantities of heavy metal(loid)s into the environment. This work assesses soil contamination and evaluates the ecological and human health risks due to exposure to hazardous materials. The metal assemblage identified in soil (Ag-As-Bi-Cd-Cu-W-Zn; potentially toxic elements (PTEs)) reflects the influence of the tailings, due to several agents including aerial dispersion. PTEs and $\mathrm{pH}$ display a positive correlation confirming that heavy metal mobility is directly related to $\mathrm{pH}$ and, therefore, affects their availability. The estimated contamination factor classified $92.6 \%$ of soil samples as moderately to ultra-highly polluted. The spatial distribution of the potential ecological risk index classified the topsoil as being of a very high ecological risk, consistent with wind direction. Non-carcinogenic hazard of topsoil, for children (1-6 years), 
showed that for As the non-carcinogenic hazard represents a high health risk. The carcinogenic risks, both for children and adult alike, reveal a very high cancer risk mostly due to As ingestion.

Keywords: Panasqueira mine; potential toxic elements; modified contamination degree; non-carcinogenic hazard; carcinogenic risk; potential ecological risk factor and risk index

\section{Introduction}

Mine tailings, with considerable amounts of sulfides, left in the vicinity of environmentally sensitive locations, constitute one of the greatest threats to the surrounding environment. These materials when exposed to air and water are oxidized through chemical, electrochemical, and biological reactions, forming ferric hydroxides and sulfuric acid, leading to the generation of acid mine drainage with high contents of metals and sulfates, related to the alteration of sulfides, the equilibrium of which depends on their solubility [1-5].

Soil is prone to contamination both from hydrological and atmospheric sources. When soil is the receptor of tailings drainage, originating from metal mining and smelting, this waste disposal causes a major impact, and poses serious environmental concerns [6]. As a direct result of the mining activities, soil is generally, affected over a considerable area. The soil fine fraction is usually enriched in metals, due to the relative large surface area of fine particles that facilitate adsorption and metal binding to iron and manganese oxides and to organic matter [7,8]. Wind-blown dust originating from polluted soil is responsible for the aerial dispersion of trace metals [7]. Exposure to these hazardous elements may have different pathways, e.g., through the direct ingestion of soils and dust, ingestion of vegetables grown on contaminated soil or dust adhering to plants or dust inhalation. According to several authors [9-14] the studies dealing with the bioavailability and bioaccessibility of metal(loid) contaminants in highly-polluted soil are extremely useful to understand the possible effect on biota, and particularly on human health due to the exposure to these contaminants [12,15].

Among the purposes of environmental analysis are the determination of the geochemical background and natural concentrations of the chemical constituents in environment-background monitoring, as well as to determine the concentration of harmful pollutants in environment-pollution monitoring [16]. The sorption-desorption soil characteristics generally control the mobility and availability of heavy metals [17]. Heavy metal availability in soil depends on a number of factors, including Soil Organic Matter (SOM) and $\mathrm{pH}$ [18]. Soil $\mathrm{pH}$ plays the most important role in determining metal speciation, solubility from mineral surfaces, movement and bioavailability of metals [19-21]. Several laboratory experiments have shown that heavy metal mobility and availability have a negative correlation with pH [22]. Further, [23-25] documented that metal mobility and availability increases with the decrease of soil $\mathrm{pH}$, thus enhancing the uptake of heavy metals by plants and, thereby, posing a threat to human health [26].

Exposure to increasing amounts of metal(loid)s in environmental and occupational settings is a reality worldwide, affecting a significant number of individuals. Most metal(loid)s are very toxic to living organisms and even those considered as essential can be toxic when in excess. They can disturb 
important biochemical processes, constituting an important threat for human health. Major health effects include development retardation, endocrine disruption, kidney damage, immunological and neurological effects, and several types of cancer [27]. The identification of potential threats to human health and natural ecosystems is useful information [16]. The quantification of all the types of risks and the determination of the total risk of metal(loid)s to the exposed population through oral intake, inhalation and dermal contact [28] is also very important. Risk assessment is typically a multistep process of identifying, defining, and characterizing potentially adverse consequences of exposure to hazardous materials [28]. According to the Toxic Substances Portal [29], Ag, As, Cd, Cu, W and Zn are known to be toxic to humans, while arsenic and cadmium are classified as human carcinogens. Some studies also consider that Bi causes acute toxicity, and large doses can be fatal [30,31]. However, as $\mathrm{Bi}$ is considered to be one of the less toxic heavy metals, it is not included in this analysis.

In a previous paper from the same authors [32], several variables ( $\mathrm{Ag}, \mathrm{As}, \mathrm{Bi}, \mathrm{Cd}, \mathrm{Cu}, \mathrm{W}$ and $\mathrm{Zn}$ ) showed moderate to strong correlation in the Panasqueira topsoil. This indicates an anthropogenic origin, especially linked to aerial transportation and deposition and/or to a geogenic origin. The main goals of the present study are: (a) establishment of the relationship between Potentially Toxic Elements (PTEs) with depth and soil $\mathrm{pH}$; (b) assessment of soil contamination using a contamination factor for each pollutant; and (c) determination and evaluation of the ecological and human health risks due to exposure to hazardous materials.

\section{Materials and Methods}

\subsection{Study Area}

The active Panasqueira mine, exploited since the last decade of the 19th century, is located in Central Portugal (UTM (Universal Transverse Mercator) 29N, P 4445620.79, M 606697.31; Figure 1). It is considered to have the largest Sn-W deposit of Western Europe [33]. The geology has been extensively studied by many researchers [34-44]. Briefly, the Panasqueira deposit is a classic example of postmagmatic hydrothermal ore deposit, which is associated with Hercynian plutonism [36,41]. The paragenesis is complex with four stages of mineral formation identified: 1st stage, the oxide silicate phase (quartz, wolframite; cassiterite); 2nd phase, the main sulphide phase (pyrite, arsenopyrite, pyrrhotite, sphalerite, chalcopyrite); 3rd stage, the pyrrhotite alteration phase (marcasite, siderite, galena, $\mathrm{Pb}-\mathrm{Bi}-\mathrm{Ag}$ sulphosalts); and 4th stage, the late carbonate phase (dolomite, calcite) [38-49]. The Panasqueira deposit contains significant amounts of wolframite, arsenopyrite, chalcopyrite and cassiterite [34].

The long history of exploitation is testified by the presence of a huge amount of tailings and other debris (Figure 1b). The piles (Rio $\sim 1.2$ million $\mathrm{m}^{3}$; Barroca Grande $\sim 7.0$ million $\mathrm{m}^{3}$ ) and the mud dams (Rio $\sim 0.7$ million $\mathrm{m}^{3}$; Barroca Grande $\sim 1.2$ million $\mathrm{m}^{3}$ ) are exposed to atmospheric conditions, and are being altered by chemical, physical and geotechnical activities. On the top of the Rio tailings, an arsenopyrite stockpile ( $\left.\sim 9400 \mathrm{~m}^{3}\right)$ was deposited and remained exposed until 2006 [41].

Topography ranges in altitude from 350 to $1080 \mathrm{~m}$ [47], with deep valleys of about $9 \%-25 \%$ inclination, constraining the soil into a very thin layer. Climate is severe, with dry and hot summers and very cold, rainy and windy winters. The annual precipitation ranges between 1200 and $1400 \mathrm{~mm}$ 
with frequent snow falls, particularly above $700 \mathrm{~m}$ altitude. The mean annual temperature is $12{ }^{\circ} \mathrm{C}$, ranging from $0{ }^{\circ} \mathrm{C}$ during the winter to $30{ }^{\circ} \mathrm{C}$ in the summer. The streams are generally dry in the summer and flooded in the winter. The prevailing wind in the area is NW-SE, with mean wind speeds of $4.22 \mathrm{~m} / \mathrm{s}(h=10 \mathrm{~m}), 5.55 \mathrm{~m} / \mathrm{s}(h=40 \mathrm{~m})$ and $6.21 \mathrm{~m} / \mathrm{s}(h=80 \mathrm{~m})($ Figure 1c) [48-50]. The small villages around the mine have a historical dependence on soil and water use drinking water, agriculture, cattle rearing, fishing and forestry.

Figure 1. (a) Synthetic map of Portugal showing the location of Panasqueira mining area; (b) details of the study area, main geological units and soil samples grid - geological map adapted from $[34,41,45]$; (c) wind rose of the prevailing winds on the top of the mine (Barroca Grande tailing); and (d) on the top of a mountain $800 \mathrm{~m}$ north of the mine [46].
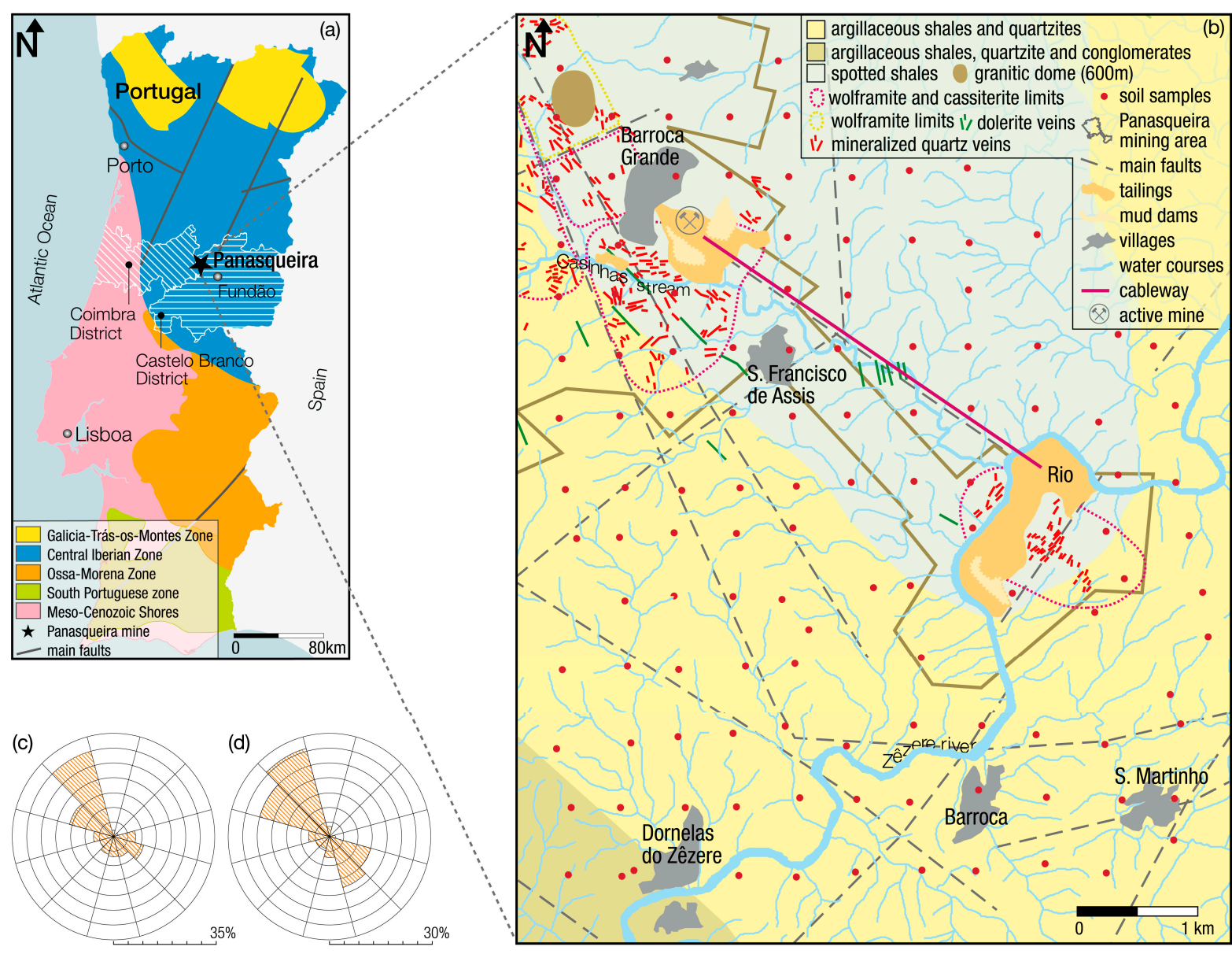

\subsection{Field Sampling and Sample Preparation}

Soil samples were collected according to a predefined grid (spaced $\sim 400 \mathrm{~m}$-Figure 1b). Two types of soil samples were collected at each sampling site: 122 topsoil $(0-15 \mathrm{~cm})$ samples and 116 subsoil samples collected below $15 \mathrm{~cm}$ depth. The difference in the total number of samples of each soil type is due to the presence at six sites of incipient and thin lithic soil derived from a substrate of metasediments. Topsoil samples were collected for the characterization of superficial contamination derived from the tailings, and subsoil samples to assess the extent of contamination at depth and simultaneously to identify geogenic markers. Approximately $50 \%$ of all samples were collected in duplicate. To establish 
the local geochemical background, 47 unaffected soil samples $(\mathrm{Bk})$ were also collected outside the contaminated area (Casegas area located NE, out of the influence of the Barroca Grande prevailing winds). The coordinates of each sample were determined by GPS and georeferenced with UTM (Universal Transverse Mercator) coordinates. All soil samples were collected after clearing the soil surface of superficial debris and vegetation, and placed in polyethylene bags. Samples were dried in a thermostatically controlled oven at $40{ }^{\circ} \mathrm{C}$, disaggregated in a porcelain mortar, sieved $(<2 \mathrm{~mm})$, homogenized, split into aliquots and the analytical aliquot pulverized to $<170 \mu \mathrm{m}$ in a pre-cleaned mechanical agate mill for chemical analysis.

\subsection{Chemical Analysis}

Soil samples were submitted for multi-element analysis at the ACME Analytical Laboratories, which is an ISO 9002 Accredited Lab (Vancouver, Canada). A sample weight of $0.5 \mathrm{~g}$ was leached in hot $\left(95^{\circ} \mathrm{C}\right)$ aqua regia $\left(\mathrm{HCl}-\mathrm{HNO}_{3}-\mathrm{H}_{2} \mathrm{O}\right)$, and concentrations were determined by Inductively Coupled Plasma Mass Spectrometry (ICP-MS) for $\mathrm{Ag}, \mathrm{As}, \mathrm{Bi}, \mathrm{Cd}, \mathrm{Cu}, \mathrm{W}$ and $\mathrm{Zn}$ (detection limits of $\mathrm{Ag}, \mathrm{Bi}$, $\mathrm{Cd}, \mathrm{Cu}, \mathrm{W}<0.1 \mathrm{mg} \cdot \mathrm{kg}^{-1}$; As $\left.<0.5 \mathrm{mg} \cdot \mathrm{kg}^{-1} ; \mathrm{Zn}<1 \mathrm{mg} \cdot \mathrm{kg}^{-1}\right)$.

Accuracy and analytical precision were determined using analytical results of certified reference materials (standards C3 and G-2) and duplicate samples in each analytical batch. The results were within the $95 \%$ confidence limits of the recommended values given for the certified materials. The Relative Standard Deviation (RSD) was between $5 \%$ and $10 \%$.

Soil $\mathrm{pH}$ : numerous studies have verified that soil $\mathrm{pH}$ has a great effect on metal bioavailability [16,51,52]. The $\mathrm{pH}$ gives an indication of the acidity and alkalinity of soil. Many chemical reactions are $\mathrm{pH}$ dependent, and knowledge of the $\mathrm{pH}$ enables the prediction of the extent and speed of chemical reactions [53]. The procedure adopted for the determination of $\mathrm{pH}$ was modified from [54]. A suspension of soil was made up in five times its volume of a $0.01 \mathrm{~mol} / \mathrm{L}$ solution of calcium chloride $\left(\mathrm{CaCl}_{2}\right)$ in water. The $\mathrm{pH}$ was measured using a calibrated $\mathrm{pH}$-meter.

SOM: plays an important role in determining the fate of inorganic, as well as organic compounds in natural soil [55-58]. SOM can be roughly determined by measuring weight loss before and after ashing at $430{ }^{\circ} \mathrm{C}$. Results are typically accurate to $1 \%-2 \%$ for soil with over $10 \%$ organic matter [53]. The procedure adopted was modified from [53]. Approximately $5 \mathrm{~g}$ of each sieved sample $(<2 \mathrm{~mm})$ was placed in a crucible and dried at $105^{\circ} \mathrm{C}$ for $24 \mathrm{~h}$. After cooling in a glass desiccator its weight was determined in a mass balance (resolution $0.001 \mathrm{~g}$ ). The difference in weight gives the water content of each soil sample. The crucibles were then placed in a muffle furnace at $430{ }^{\circ} \mathrm{C}$ for $20 \mathrm{~h}$. After cooling in a glass desiccator, the weight was measured on the same mass balance. The difference from the dry state gives the soil organic content (\%).

\subsection{Data Treatment of Data}

Pearson's product-moment linear correlation coefficient matrix $(r)$ was estimated in order to determine the extent of the relationship between the PTEs, pH and SOM [53]. The normality of statistical distribution of all data was verified by the Kolmogorov-Smirnov test $(\alpha=0.05)$ and Q-Q plots. The non-normal data were subjected to a non-parametric test or converted logarithmically to 
ensure the validity of the results. The statistical analysis was performed using Six Sigma Statistica ${ }^{\circledR}$ (Stat Software Inc, Tulsa, OK, USA) and IBM ${ }^{\circledR}$ SPSS $^{\circledR}$ Statistics software (IBM, New York, NY, USA).

Analysis of Variance (ANOVA) was carried out in order to assess the relationship between the Potentially Toxic Elements and the independent variables (depth, $\mathrm{pH}$ and SOM), by a two-way ANOVA test, according to the following expression:

$$
Z_{\mathrm{ijk}}=\mu+\propto_{\mathrm{i}}+\beta_{\mathrm{j}}+\gamma_{\mathrm{ij}}+\varepsilon_{\mathrm{ijk}}
$$

where, $Z=$ the $k$ th observation of the PTE taken at $j$ th depth $(j=1$ or 2$)$ and $i$ th soil property $(i=1$ or 2), $\mu=$ the overall mean estimated, $\alpha=$ the depth effect, $\beta=$ the soil property (pH or SOM), $\gamma=$ the interaction between depth and the soil property, and $\varepsilon=$ the residual error [59-61].

$\log _{10}$ transformation was applied to PTEs in order to convert the data to a normal or near-normal distribution and homogeneity of variances (Levene's test, $p<0.05$ ). For the two-way analysis of variance, samples were classified according to $\mathrm{pH}$ values (very acid $(3.0,4.0)$, acid $(4.0,6.0)$ and neutral $(6.0,7.0))$ and $\operatorname{SOM}((3.6,10.0)$ and $(10.0,39.0)$ in $\%)$. It should be noted that the SOM classes established, were only defined for statistical purposes. In the cases where there were only two samples with neutral $\mathrm{pH}$, this particular class was not considered further.

Contamination Factor and Modified Degree of Contamination was estimated using the method proposed by [62] in sediment pollution studies, but is also applied to soil studies [63,64]. It is based on the calculation, for each pollutant, of a contamination factor $\left(C F_{i}\right)$ which is the ratio obtained by dividing the mean concentration of each metal in soil $\left(C_{i}\right)$ by its corresponding baseline or background value (estimated from samples collected outside the area influenced by the mining activities) according to [65], and as explained in [6], i.e., the background value, $C_{b}\left(\mathrm{mg} \mathrm{kg}^{-1}\right)$, for the studied elements is as follows: $\mathrm{Ag}=0.05 ; \mathrm{As}=22 ; \mathrm{Bi}=0.3 ; \mathrm{Cd}=0.01 ; \mathrm{Cu}=28 ; \mathrm{W}=0.35 ; \mathrm{Zn}=58)$ [64] ( Table 1):

$$
C F_{i}=C_{i} / C_{b}
$$

Table 1. Classification and description of the Contamination factor $(C F)$ [62] and the Modified contamination degree $(m C d)$ [66].

\begin{tabular}{cccc}
\hline $\boldsymbol{C F}$ Value & $\begin{array}{c}\text { Level of the } \\
\text { Contamination Factor }\end{array}$ & $\boldsymbol{m} \boldsymbol{C}_{\boldsymbol{d}}$ Value & $\begin{array}{c}\text { Modified Contamination } \\
\text { Degree Gradations }\end{array}$ \\
\hline \multirow{2}{*}{$0 \leq C F<1$} & Low & $0 \leq m C_{d}<1.5$ & None to very low \\
& Moderate & $2 \leq m C_{d}<4$ & Low \\
\hline $1 \leq C F<3$ & High & $4 \leq m C_{d}<8$ & Moderate \\
\hline $3 \leq C F<6$ & & $8 \leq m C_{d}<16$ & Hery high \\
\hline \multirow{2}{*}{$6 \leq C F$} & Very high & $16 \leq m C_{d}<32$ & Extremely high \\
& & $32 \leq m C_{d}$ & Ultra high \\
\hline
\end{tabular}

In [66] is presented a modified and generalized form of the [62] equation for the calculation of the overall degree of contamination $\left(m C_{d}\right)$ for each sample as below:

$$
m C_{d}=\left(\sum_{i=1}^{7} C F_{i}\right) / 7
$$


where $C F_{i}$ is the contamination factor computed for each of the seven pollutants $(\mathrm{Ag}, \mathrm{As}, \mathrm{Bi}, \mathrm{Cd}, \mathrm{Cu}$, $\mathrm{W}, \mathrm{Zn}$ ) considered in this study. In [66] is defined seven $m C_{d}$ degrees as shown in Table 1.

Potential ecological risk factor and risk index $(P E R I)$ : is defined as the sum of the risk factors, which quantitatively defines the potential ecological risk of a contaminant in a sample, i.e.:

$$
\text { PERI }_{i}=\sum_{i=1}^{7} E F_{i}=\sum_{i=1}^{7} C F_{i} \cdot T F
$$

where $P E R I_{i}$ is the Potential Ecological Risk Index for each sample $(i) ; E F_{i}$ is the monomial potential ecological risk factor; $C F_{i}$ is the single contamination factor (Equation (2)); and $T F$ is the heavy metal toxic-response factor for each element. Soil toxic-response factors were computed for the seven selected elements according to the toxic factor requirements proposed by [62]. For this estimation there were used reference guide values of igneous rock types, soil, freshwater and land plants proposed by [67], and the land animals reference values proposed by [68]. The TF values obtained were: $\mathrm{Zn}=1<$ $\mathrm{Cu}=2<\mathrm{As}=5<\mathrm{W}=15<\mathrm{Bi}=20<\mathrm{Cd}=30<\mathrm{Ag}=35$. In [62] are defined five $E F$ classes and four PERI degrees, as shown in Table 2.

Table 2. Monomial potential ecological risk factor $(E F)$ and Potential ecological risk index (PERI) classification levels [62].

\begin{tabular}{cccc}
\hline $\boldsymbol{E F}$ & $\begin{array}{c}\text { Ecological Potential Risk } \\
\text { for Single Substance }\end{array}$ & PERI & Ecological Risk \\
\hline $0 \leq E F<40$ & Low & $P E R I<150$ & Low \\
$40 \leq E F<80$ & Moderate & $150 \leq P E R I<300$ & Moderate \\
$80 \leq E F<160$ & Considerable & $300 \leq P E R I<600$ & Considerable \\
$160 \leq E F<320$ & High & $600 \leq P E R I$ & Very high \\
$320 \leq E F$ & Very high & & \\
\hline
\end{tabular}

Human health risk assessment calculations were based on the assumption that residents, both children and adults, are directly exposed to soil through three main pathways (a) ingestion; (b) dermal absorption and (c) inhalation of soil particles present in the air [69-72]. Ingestion of soil (i) occurs by eating soil particles and/or licking contact surfaces (e.g., hands). It is assumed that children present a higher ingestion rate, due to hand-to-mouth intake. Dermal absorption (ii) occurs through exposed skin, while soil is inhaled (iii) both by mouth and nose during breathing. Particles $<10 \mu \mathrm{m}\left(\mathrm{PM}_{10}\right)$ are the more relevant in this process, although larger fractions of inhaled soil are, probably, decomposed in the gastrointestinal track. It is assumed that all contaminants are absorbed, both by the gastrointestinal tract or the lung [72]. Equations (5)-(7) were used to estimate the chronic daily intake of each exposure route considered $[28,69,70,73]$, supplemented by specific quantitative information (Table 3 ):

$$
\begin{gathered}
C D I_{\text {ing }}=C_{\text {soil }} \times \frac{\operatorname{Ing} R \times E F \times E D}{B W \times A T} \times 10^{-6} \\
C D I_{\mathrm{drm}}=C_{\text {soil }} \times \frac{S A \times S A F \times D A \times E F \times E D}{B W \times A T} \times 10^{-6} \\
C D I_{\text {inh }}=C_{\text {soil }} \times \frac{\operatorname{Inh} R \times E F \times E D}{P E F \times B W \times A T}
\end{gathered}
$$


Table 3. Variables for estimation of soil residential risk in the Panasqueira mining area.

\begin{tabular}{|c|c|c|c|c|}
\hline \multirow{2}{*}{ Parameters } & \multirow{2}{*}{ Meaning } & \multicolumn{2}{|c|}{ Values } & \multirow{2}{*}{ Reference } \\
\hline & & Child & Adult & \\
\hline$A B S_{\mathrm{gi}}$ & fraction of contaminant absorbed in gastrointestinal tract & \multicolumn{2}{|c|}{$\begin{array}{l}\mathrm{Ag} \mathrm{0.04;} \mathrm{As} \mathrm{1.00;} \mathrm{Cd} \mathrm{0.025;} \\
\text { Cu 1.00; W 1.00; Zn } 1.00\end{array}$} & {$[28]$} \\
\hline$A B S_{\mathrm{drm}}$ & fraction of contaminant absorbed dermally from soil & \multicolumn{2}{|c|}{ As $0.03 ; \mathrm{Cd} 0.001$} & [28] \\
\hline$A T_{\mathrm{c}}(\mathrm{d})$ & averaging time for carcinogenic effects & \multicolumn{2}{|c|}{$L T \times 365$} & [73] \\
\hline$A T_{\mathrm{nc}}(\mathrm{d})$ & averaging time for non-carcinogenic effects & \multicolumn{2}{|c|}{$E D \times 365$} & {$[73]$} \\
\hline$B W(\mathrm{~kg})$ & average body weight & 15 & 70 & {$[69,72]$} \\
\hline$C_{\text {soil }}\left(\mathrm{mg} \cdot \mathrm{kg}^{-1}\right)$ & concentration of the element in soil & \multicolumn{2}{|c|}{-} & \\
\hline$D A$ & dermal absorption factor & \multicolumn{2}{|c|}{0.03 for As; 0.001 for other } & {$[28]$} \\
\hline$C D I_{\text {ing }}\left(\mathrm{mg} \cdot \mathrm{kg}^{-1} \cdot \mathrm{d}^{-1}\right)$ & $\begin{array}{l}\text { chronic daily intake dose } \\
\text { through ingestion }\end{array}$ & \multicolumn{2}{|c|}{ - } & Equation (5) \\
\hline$C D I_{\mathrm{drm}}\left(\mathrm{mg} \cdot \mathrm{kg}^{-1} \cdot \mathrm{d}^{-1}\right)$ & $\begin{array}{l}\text { chronic daily intake through } \\
\text { dermal contact }\end{array}$ & \multicolumn{2}{|c|}{-} & Equation (6) \\
\hline$C D I_{\text {inh }}\left(\mathrm{mg} \cdot \mathrm{m}^{-3}\right)(\mathrm{nc}),\left(\mu \mathrm{g} \cdot \mathrm{m}^{-3}\right)(\mathrm{c})$ & chronic daily intake through inhalation & \multicolumn{2}{|c|}{-} & Equation (7) \\
\hline$C S F_{\text {ing }}\left(\left(\mathrm{mg} \cdot \mathrm{kg}^{-1} \cdot \mathrm{d}^{-1}\right)^{-1}\right)$ & chronic oral slope factor & \multicolumn{2}{|c|}{ As 1.50} & {$[28]$} \\
\hline$C S F_{\mathrm{drm}}$ & chronic dermal slope factor & \multicolumn{2}{|c|}{$C S F_{\text {ing }} / A B S_{\text {gi }}$} & {$[28]$} \\
\hline$E D(\mathrm{yr})$ & exposure duration & 6 & 24 & [73] \\
\hline$E F\left(\mathrm{~d} \cdot \mathrm{yr}^{-1}\right)$ & exposure frequency & \multicolumn{2}{|c|}{350 residents } & {$[73]$} \\
\hline$E T\left(\mathrm{~h} \cdot \mathrm{d}^{-1}\right)$ & exposure time & \multicolumn{2}{|c|}{24 residents } & {$[73]$} \\
\hline $\operatorname{Ing} R\left(\mathrm{mg} \cdot \mathrm{d}^{-1}\right)$ & soil ingestion rate & 200 & 100 & {$[73]$} \\
\hline $\operatorname{Inh} R\left(\mathrm{~m}^{3} \cdot \mathrm{d}^{-1}\right)$ & inhalation rate & 7.6 & 20 & [72] \\
\hline $\operatorname{IUR}\left(\left(\mu \mathrm{g} \cdot \mathrm{m}^{-3}\right)^{-1}\right)$ & chronic inhalation slope factor & As $4.3 \times 1$ & $1.8 \times 10^{-3}$ & {$[74]$} \\
\hline$L T(\mathrm{yr})$ & lifetime expected at birth & \multicolumn{2}{|c|}{78 national } & {$[75]$} \\
\hline $\operatorname{PEF}\left(\mathrm{m}^{3} \cdot \mathrm{kg}^{-1}\right)$ & particle emission factor & \multicolumn{2}{|c|}{$1.36 \times 10^{9}$} & {$[73]$} \\
\hline$S A\left(\mathrm{~cm}^{2}\right)$ & exposed skin area & 2800 & 5700 & {$[73]$} \\
\hline$S A F\left(\mathrm{mg} \cdot \mathrm{cm}^{-2}\right)$ & skin adherence factor & 0.2 & 0.07 & {$[73]$} \\
\hline$R_{f} D_{\text {ing }}\left(\mathrm{mg} \cdot \mathrm{kg}^{-1} \cdot \mathrm{d}^{-1}\right)$ & chronic oral reference dose & \multicolumn{2}{|c|}{$\begin{array}{c}\text { Ag } 5 \times 10^{-3} ; \text { As } 3 \times 10^{-4} \\
\text { Cd } 1 \times 10^{-3} ; \mathrm{Cu} 4 \times 10^{-2} \\
\text { Zn } 0.3\end{array}$} & {$[74]$} \\
\hline$R_{f} D_{\mathrm{drm}}$ & chronic dermal reference dose & \multicolumn{2}{|c|}{$R f D_{\text {ing }} \times A B S_{\mathrm{gi}}$} & [28] \\
\hline$R_{f} D_{\text {inh }}\left(\mathrm{mg} \cdot \mathrm{m}^{-3}\right)$ & chronic inhalation reference dose & As $1.5 \times$ & $\mathrm{d} 1 \times 10^{-5}$ & {$[28]$} \\
\hline
\end{tabular}

The carcinogenic and non-carcinogenic side effects for each PTE were computed individually, as toxicity calculation uses different computational methods [76]. For each element and pathway, the non-cancer toxic risk was estimated by computing the Hazard Quotient ( $H Q$, also known as non-cancer risk-Equation (8)) for systemic toxicity [73]. If $H Q$ exceeds unity, it indicates that non-carcinogenic effects might occur. To estimate the overall developing hazard of non-carcinogenic effects, it is assumed that toxic risks have additive effects. Therefore, it is possible to calculate the cumulative non-carcinogenic hazard index $(H I)$, which corresponds to the sum of HQ for each pathway (Equation (9)) [69,77]. Values of $H I<1$ indicate that there is no significant risk of non-carcinogenic effects. While, values of $\mathrm{HI}>1$ imply that there is a probability of occurrence of non-carcinogenic effects, and are enhanced with increasing HI values [73]. The toxicity levels for each element were taken from The Risk Assessment 
Information System (RAIS) [28]. The probability of an individual developing any type of cancer over a lifetime, as a result of exposure to the carcinogenic hazards, was computed for each pathway according to Equation (10) [78]. The carcinogenic risk was estimated by the sum of total cancer risk (Equation (11)). A cancer risk below $1 \times 10^{-6}$ is considered insignificant. The result of $1 \times 10^{-6}$ is classified as the carcinogenic target risk. If the cancer risk is above $1 \times 10^{-4}$ it is qualified as unacceptable $[69,79,80]$ :

$$
\begin{gathered}
H Q=\frac{C D I_{\text {pathway }}}{R_{\mathrm{f}} D} \\
H I=\sum H Q=H Q_{\text {ing }}+H Q_{\mathrm{drm}}+H Q_{\mathrm{ihn}} \\
\text { Risk }=\sum \text { Risk }_{\text {pathway }}=C D I_{\text {pathway }} \times C S F_{\text {pathway }}=\text { Risk }_{\text {ing }}+\text { Risk }_{\text {drm }}+\text { Risk }_{\text {ihn }} \\
=C D I_{\text {ing }} \times C F S_{\text {ing }}+C D I_{\text {inh }} \times I U R+\frac{C D I_{\mathrm{drm}} \times C S F_{\text {ing }}}{A B S_{\text {gi }}}
\end{gathered}
$$

Reference toxicity values were estimated as given in RAIS [28].

Spatial Estimation of extrapolated concentration values of chemical elements and contamination factors for the plotting of maps was based on geostatistics by extracting the necessary parameters for Ordinary Kriging from the variograms of each variable. Variograms were constructed and modelled with Surfer ${ }^{\circledR}$ (v. 8, Golden Software Inc, Golden, CO, USA), and the kriged estimations by Ordinary Kriging were also performed with Surfer ${ }^{\circledR}$.

\section{Results and Discussion}

\subsection{Distribution of $A g, A s, B i, C d, C u, W$ and $Z n$ in Soil Samples}

Previous studies carried out in the Panasqueira area [6,43,44], allowed, through the topsoil concentrations, the characterization of the anthropogenic soil contamination due to the presence of tailings and open air impoundments.

Descriptive statistical parameters (median and range) for $\mathrm{pH}, \mathrm{SOM}, \mathrm{Ag}, \mathrm{As}, \mathrm{Bi}, \mathrm{Cd}, \mathrm{Cu}, \mathrm{W}$ and $\mathrm{Zn}$ are summarized in Table 4. The individual element values are compared with the corresponding local geochemical background levels, and also with reference values from the literature.

All samples, both topsoil and subsoil, have a $\mathrm{pH}$ lower than 7. In particular, topsoil $\mathrm{pH}$ values range from 3.2 to $6.6 ; 35.9 \%$ of topsoil samples have $\mathrm{pH}$ values between 3.0 and $4.0 ; 59.2 \%$ are between 4.0 and $5.0 ; 4.2 \%$ from 5.0 to 6.0 , and $1.7 \%$ from 6.0 to 7.0 , i.e., generally very acid to acid according to the United States Department of Agriculture classification [81]. As shown in Figure 2 (pH (a)), it is possible to identify that the areas with higher values are located around the villages Barroca Grande, S. Francisco de Assis, Rio, Barroca, Dornelas do Zêzere and S. Martinho. Around Rio and Barroca Grande tailings, the soil $\mathrm{pH}$ is above the 75 th percentile $(<4.1)$. The subsoil $\mathrm{pH}$ ranges from 3.6 to 6.2 : $23.0 \%$ of the subsoil samples have $\mathrm{pH}$ values between 3.0 and $4.0 ; 73.5 \%$ are between 4.0 and 5.0; $2.7 \%$ from 5.0 to 6.0 , and $0.9 \%$ from 6.0 to 7.0 , i.e., also generally very acid to acid. The highest $\mathrm{pH}$ value found in subsoil samples was located in Rio village (Figure $2 \mathrm{pH}(\mathrm{b})$ ) on the north section of the Rio tailings. In the surroundings of S. Francisco de Assis, Barroca Grande and Dornelas do Zêzere 
villages, it is possible to identify some agricultural soil with $\mathrm{pH}>4.6$. Possibly these slightly higher $\mathrm{pH}$ values are due to land agricultural beneficiation techniques. Nevertheless, the soil of the present study area is overall classified as very acid to acid.

Figure 2. Spatial distribution of $\mathrm{pH}$ and soil organic matter (SOM, \%) and $\mathrm{Ag}\left(\mathrm{mg} \mathrm{kg}^{-1}\right)$ for topsoil (a) and subsoil (b). Percentile class limits at P5, P10, P25, P50, P75, P90, P95 and P97.5. In blue are represented the main water courses, in grey the villages and in white the main tailings and dams. The green dashed lines represent the Ag background levels.
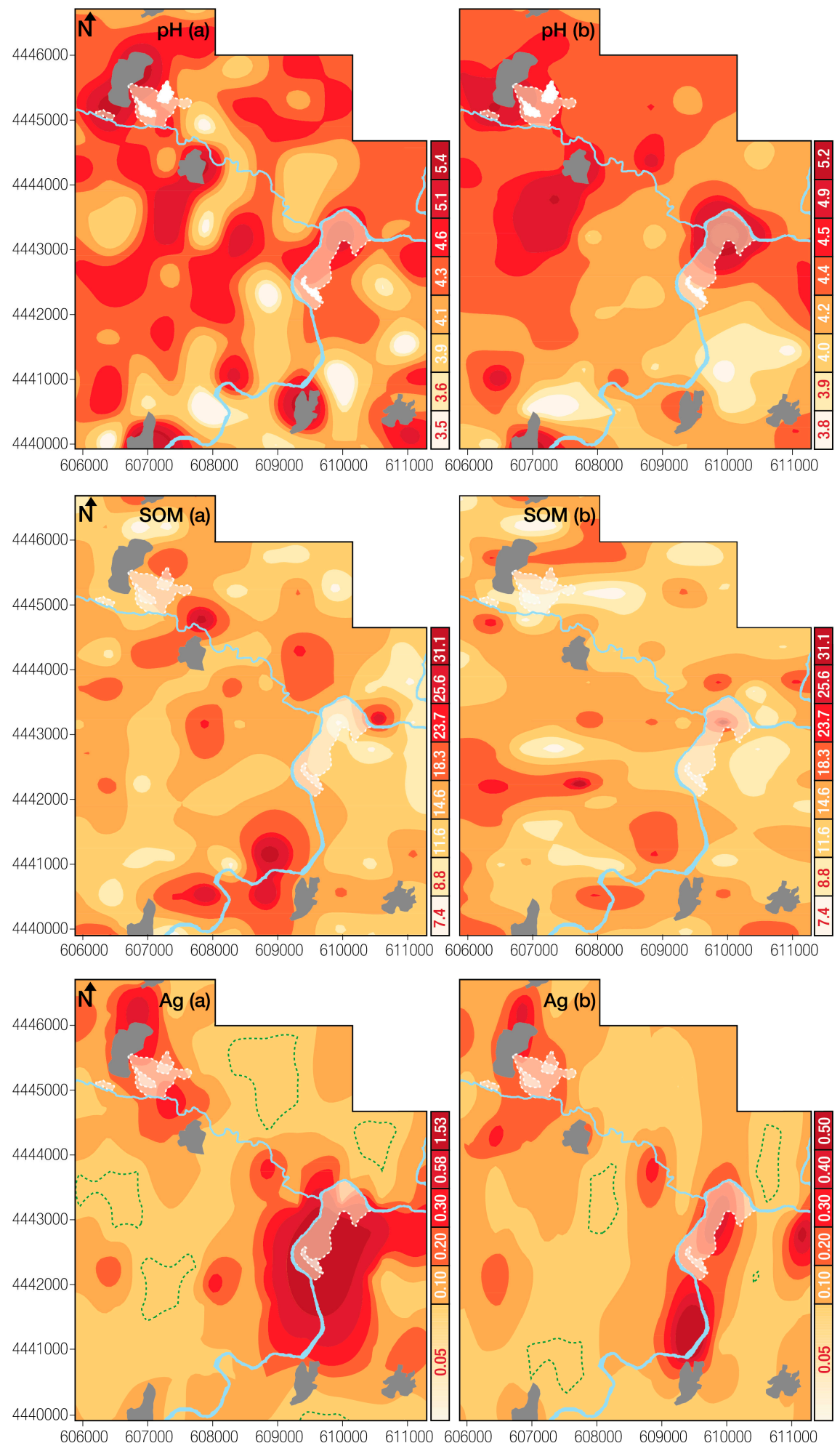
Table 4. Median, minimum and maximum concentrations values of topsoil and subsoil samples from Panasqueira mine and surrounding environment compared with international data. Casegas area, considered as representative of geochemical background (Bk).

\begin{tabular}{|c|c|c|c|c|c|c|c|c|c|c|}
\hline \multicolumn{2}{|c|}{ Units } & pH & $\begin{array}{c}\text { SOM } \\
\% \\
\end{array}$ & $\begin{array}{c}\text { Ag } \\
\mathrm{mg} \cdot \mathrm{kg}^{-1}\end{array}$ & $\begin{array}{c}\mathrm{As} \\
\mathrm{mg} \cdot \mathrm{kg}^{-1}\end{array}$ & $\begin{array}{c}\text { Bi } \\
\mathrm{mg} \cdot \mathrm{kg}^{-1}\end{array}$ & $\begin{array}{c}\mathrm{Cd} \\
\mathrm{mg} \cdot \mathrm{kg}^{-1}\end{array}$ & $\begin{array}{c}\mathrm{Cu} \\
\mathrm{mg} \cdot \mathrm{kg}^{-1}\end{array}$ & $\begin{array}{c}\text { W } \\
\mathrm{mg} \cdot \mathrm{kg}^{-1}\end{array}$ & $\begin{array}{c}\mathrm{Zn} \\
\mathrm{mg} \cdot \mathrm{kg}^{-1}\end{array}$ \\
\hline \multirow{3}{*}{$\begin{array}{c}\text { Topsoil } \\
(n=122)\end{array}$} & Median & 4.1 & 14.6 & 0.1 & 65 & 0.9 & 0.2 & 35 & 6 & 70 \\
\hline & Min-Max & $3.2-6.6$ & $5.7-39.0$ & $0.05-1.7$ & $17-1503$ & $0.3-65$ & $0.1-3$ & 10-292 & $0.2-200$ & 22-199 \\
\hline & Sk & 1.59 & 1.2 & 4.72 & 6.98 & 9.21 & 3.77 & 4.80 & 5.40 & 1.38 \\
\hline \multirow{3}{*}{$\begin{array}{l}\text { Subsoil } \\
(n=116)\end{array}$} & Median & 4.2 & 10.2 & 0.1 & 52 & 0.6 & 0.1 & 33 & 3 & 70 \\
\hline & Min-Max & $3.6-6.2$ & $3.6-19.5$ & $0.1-0.6$ & $8-350$ & $0.2-15$ & $0.1-1.5$ & $12-146$ & $0.1-29$ & 16-192 \\
\hline & Sk & 2.09 & 0.23 & 1.98 & 2.05 & 5.51 & 3.65 & 2.86 & 2.51 & 1.08 \\
\hline \multirow{3}{*}{$\begin{array}{l}\text { Geochemical } \\
\text { background }\end{array}$} & Topsoil & 4.2 & 14.5 & 0.1 & 63 & 0.8 & 0.20 & 34 & 4.4 & 68 \\
\hline & Subsoil & 4.3 & 10.0 & 0.1 & 49 & 0.6 & 0.10 & 31 & 2.5 & 68 \\
\hline & Bk & 3.98 & 10.5 & 0.05 & 22 & 0.3 & 0.01 & 28 & 0.4 & 58 \\
\hline \multicolumn{2}{|c|}{ Data from literature } & $6.0-8.0^{\mathrm{a}}$ & $1-20^{b}$ & $0.07^{\mathrm{c}}$ & $11^{\mathrm{d}}$ & $0.3^{\mathrm{c}}$ & $0.1^{\mathrm{d}}$ & $16^{\mathrm{d}}$ & $1^{\mathrm{d}}$ & $55^{d}$ \\
\hline
\end{tabular}

Notes: SOM, soil organic matter; Sk, Skewness; Bk, background values, calculated according the [65] paradigm and confirmed by the [82] methods; ${ }^{\text {a }}$ Ontario reference values [83]; ${ }^{b}$ Normal Ranges in Soils $[16,84,85] ;{ }^{c}$ Mean World Soil [67,86]; ${ }^{\mathrm{d}}$ Median values for Portuguese Soil [87].

The topsoil SOM values range from 5.7\% to 39.0\% (see Table 4 and Figure 2 SOM (a)), while the subsoil SOM values vary from 3.6\% to $19.5 \%$ (see Table 4 and Figure 2 SOM (b)). Comparing the topsoil and subsoil $\mathrm{pH}$ and SOM maps (Figure 2 and Table 4) is possible to observe that areas with the highest $\mathrm{SOM}$ values are related to areas with the lowest $\mathrm{pH}$ values.

To evaluate the presence of possible local anomalies the $\mathrm{Ag}$ (Figure 2), $\mathrm{As}, \mathrm{Bi}, \mathrm{Cd}$ (Figure 3), $\mathrm{Cu}$, $\mathrm{W}, \mathrm{Zn}$ (Figure 4) median and maximum values, observed in topsoil, were compared with the corresponding results in subsoil samples. Although the results tabulated in Table 4 show that Ag, As, $\mathrm{Bi}, \mathrm{Cu}, \mathrm{W}$, and $\mathrm{Zn}$ present highest median and maximum values for topsoil when compared with subsoil, the paired samples $t$-test indicates that there are significant differences between soil samples at both depths for the elements $\mathrm{As}, \mathrm{Bi}$ and W. Additionally, the results clearly show that there are higher contents in soil samples at both depths, when compared with the local geochemical background. The behavior of the topsoil element concentrations may reflect the influence of the Barroca Grande and Rio tailings and open air impoundments, possibly caused by aerial transport and deposition.

Topsoil samples, as shown in Table 5, have many strong to very strong correlation coefficients, i.e., $\mathrm{As} / \mathrm{Ag}, \mathrm{As} / \mathrm{Bi}, \mathrm{As}, \mathrm{Cd}, \mathrm{As} / \mathrm{Cu}, \mathrm{As} / \mathrm{W}, \mathrm{Ag} / \mathrm{Bi}, \mathrm{Ag} / \mathrm{Cu}, \mathrm{As} / \mathrm{W}, \mathrm{Bi} / \mathrm{Cd}, \mathrm{Bi} / \mathrm{Cu}, \mathrm{Bi} / \mathrm{W}, \mathrm{Cd} / \mathrm{Cu}, \mathrm{Cd} / \mathrm{W}, \mathrm{Cd} / \mathrm{Zn}$, $\mathrm{Cu} / \mathrm{W}$. The strongest correlations are between $\mathrm{Ag} / \mathrm{Cu}(0.94), \mathrm{As} / \mathrm{Ag}(0.90)$ and $\mathrm{Bi} / \mathrm{W}(0.90)$. There is also a positive intermediate correlation $(r=0.31$ to 0.70$)$ between PTEs and $\mathrm{pH}$. Several authors claim that heavy metal mobility holds a positive correlation with $\mathrm{pH}[18,88,89]$. It is well known that $\mathrm{pH}$ affects heavy metal availability, since it is the major factor in controlling the ability of soil to retain heavy metals in an exchangeable form [21]. With low SOM the $\mathrm{pH}$ values may become relatively more important for the partitioning of metals. Most elements exhibit a weak negative correlation with SOM. For subsoil samples the PTEs correlation also presents some strong correlation coefficients (Table 5), but they are overall lower than in topsoil. The stronger correlations are between $\mathrm{As} / \mathrm{Bi}(r=0.75)$ and 
$\mathrm{Bi} / \mathrm{Cu}(r=0.69)$. At this depth, $\mathrm{pH}$ is also the most significant soil property, presenting weak to intermediate positive correlations with the PTEs, except W.

Figure 3. Spatial distribution of $\mathrm{As}, \mathrm{Bi}, \mathrm{Cd}\left(\mathrm{mg} \cdot \mathrm{kg}^{-1}\right)$ values for topsoil (a) and subsoil (b). Percentile class limits at P5, P10, P25, P50, P75, P90, P95 and P97.5. The green dashed lines represent the elements background levels. In blue are represented the main water courses, in grey the villages and in white the main tailings and dams.
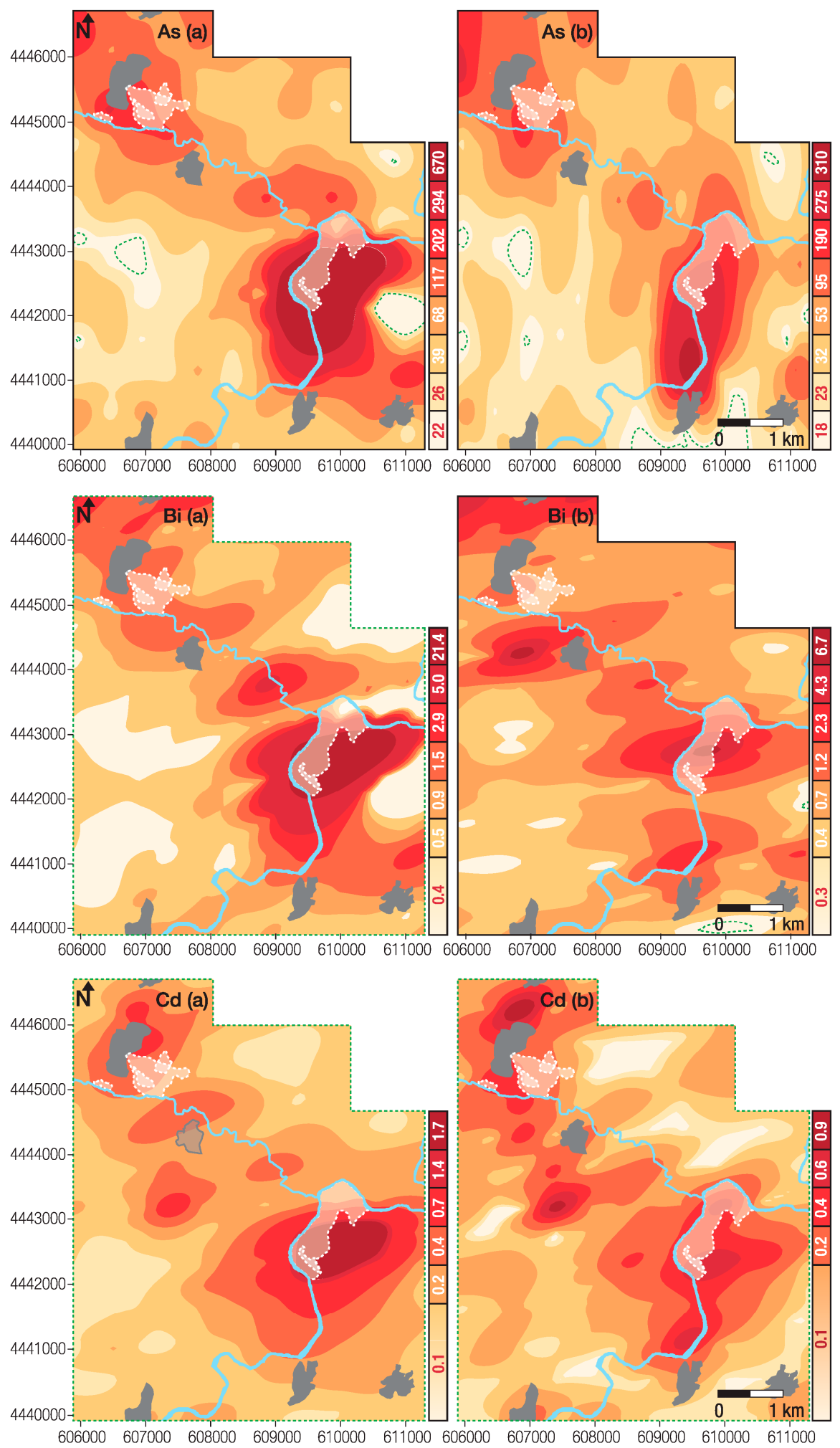
Figure 4. Spatial distribution of $\mathrm{Cu}, \mathrm{W}, \mathrm{Zn}\left(\mathrm{mg} \cdot \mathrm{kg}^{-1}\right)$ values for topsoil (a) and subsoil (b). Percentile class limits at P5, P10, P25, P50, P75, P90, P95 and P97.5. The green dashed lines represent the elements background levels. In blue are represented the main water courses, in grey the villages and in white the main tailings and dams.
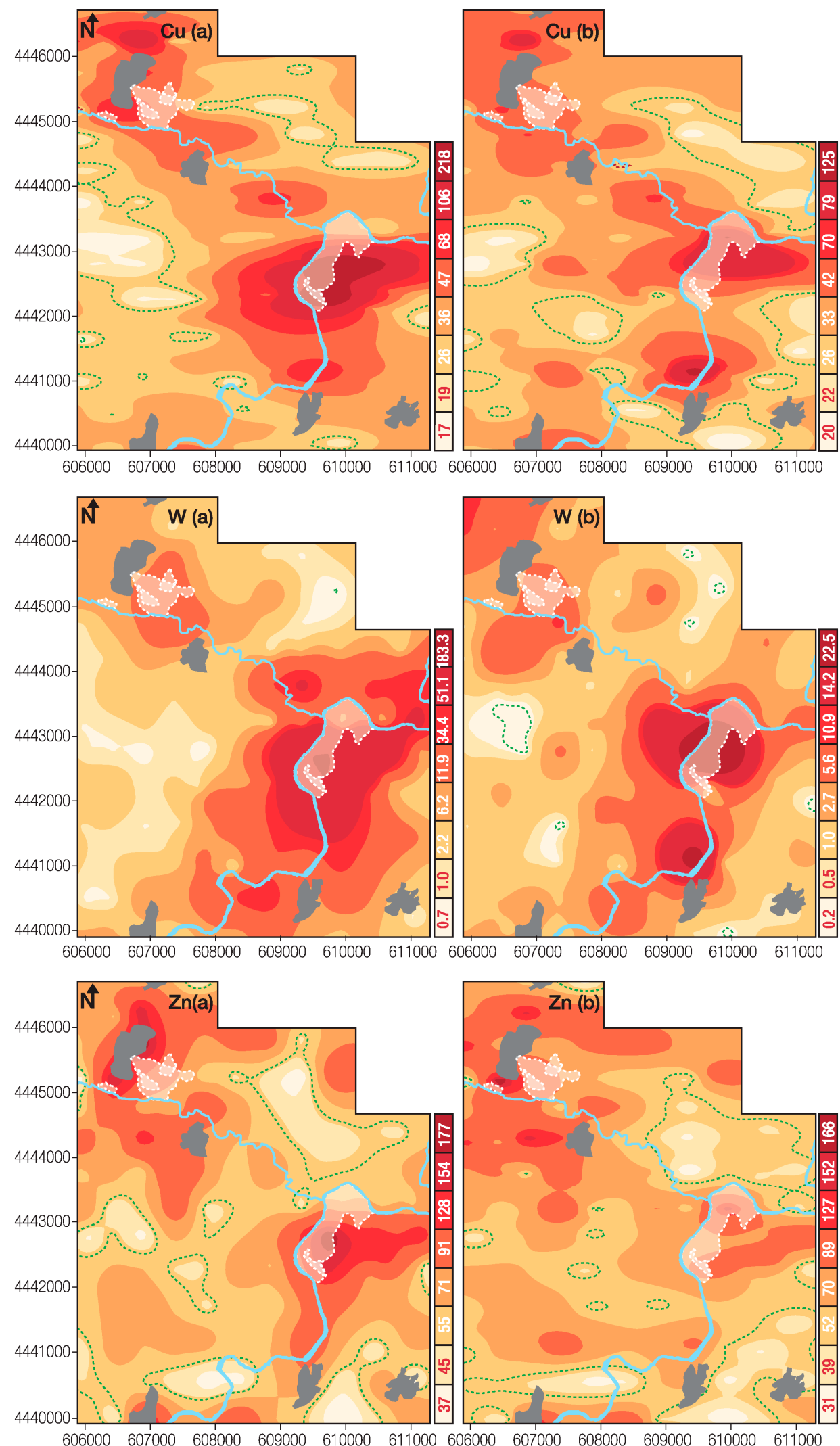
Table 5. Pearson's linear product-moment correlation coefficients for $\mathrm{Ag}, \mathrm{As}, \mathrm{Bi}, \mathrm{Cd}, \mathrm{Cu}$, $\mathrm{W}, \mathrm{Zn}, \mathrm{pH}$ and SOM in topsoil $(n=122)$ and subsoil $(n=116)$ samples.

\begin{tabular}{ccccccccccc}
\hline Var & & $\mathbf{A g}$ & $\mathbf{A s}$ & $\mathbf{B i}$ & $\mathbf{C d}$ & $\mathbf{C u}$ & $\mathbf{W}$ & $\mathbf{Z n}$ & $\mathbf{p H}$ & $\mathbf{S O M}$ \\
\hline & $\mathbf{A g}$ & 1.00 & $\mathbf{0 . 9 0} * *$ & $\mathbf{0 . 8 4} * *$ & $\mathbf{0 . 7 9} * *$ & $\mathbf{0 . 9 4} * *$ & $\mathbf{0 . 8 3} * *$ & $0.51 * *$ & $\mathbf{0 . 7 0} * *$ & -0.1 \\
& $\mathbf{A s}$ & & 1.00 & $\mathbf{0 . 8 4} * *$ & $\mathbf{0 . 7 7} * *$ & $\mathbf{0 . 8 9} * *$ & $\mathbf{0 . 8 1} * *$ & $0.44 * *$ & $0.37 * *$ & -0.09 \\
& $\mathbf{B i}$ & & & 1.00 & $\mathbf{0 . 8 2} * *$ & $\mathbf{0 . 8 7} * *$ & $\mathbf{0 . 9 0} * *$ & $0.44 * *$ & $0.54 * *$ & -0.14 \\
& $\mathbf{C d}$ & & & & 1.00 & $\mathbf{0 . 8 6} * *$ & $\mathbf{0 . 7 9} * *$ & $\mathbf{0 . 6 8} * *$ & $0.42 * *$ & -0.07 \\
Topsoil & $\mathbf{C u}$ & & & & & 1.00 & $\mathbf{0 . 8 0} * *$ & $\mathbf{0 . 6 0} * *$ & $\mathbf{0 . 6 1} * *$ & -0.14 \\
& $\mathbf{W}$ & & & & & & 1.00 & $0.38 * *$ & $0.46 * *$ & 0.01 \\
& $\mathbf{Z n}$ & & & & & & & 1.00 & $0.31 * *$ & -0.15 \\
& $\mathbf{p H}$ & & & & & & & & 1.00 & $-0.40 * *$ \\
& $\mathbf{S O M}$ & & & & & & & & & 1.00 \\
\hline & $\mathbf{A g}$ & 1.00 & $0.43 * *$ & $0.34 * *$ & $0.45 * *$ & $0.42 * *$ & $0.36 * *$ & $0.43 * *$ & $0.30 * *$ & 0.15 \\
& $\mathbf{A s}$ & & 1.00 & $\mathbf{0 . 7 5} * *$ & $0.43 * *$ & $\mathbf{0 . 5 9} * *$ & $0.49 * *$ & $0.30 * *$ & 0.09 & -0.01 \\
& $\mathbf{B i}$ & & & 1.00 & $0.50 * *$ & $\mathbf{0 . 6 9} * *$ & $\mathbf{0 . 5 6} * *$ & $0.35 * *$ & 0.04 & -0.01 \\
& $\mathbf{C d}$ & & & & 1.00 & $\mathbf{0 . 5 3} * *$ & $0.43 * *$ & $\mathbf{0 . 5 7} * *$ & 0.17 & -0.09 \\
Subsoil & $\mathbf{C u}$ & & & & & 1.00 & $0.44 * *$ & $\mathbf{0 . 5 6} * *$ & 0.11 & -0.17 \\
& $\mathbf{W}$ & & & & & & 1.00 & 0.14 & $-0.21 *$ & 0.16 \\
& $\mathbf{Z n}$ & & & & & & & 1.00 & $0.45 * *$ & $-0.23 *$ \\
& $\mathbf{p H}$ & & & & & & & & 1.00 & $-0.35 *$ \\
$\mathbf{S O M}$ & & & & & & & & & 1.00 \\
\hline
\end{tabular}

Notes: ** Correlation is significant at the 0.01 level (2-tailed); * Correlation is significant at the 0.05 level (2-tailed).

In order to identify the most important factor controlling the different PTEs spatial differences concentrations, a two-way ANOVA was performed [90]. In this study, two models were selected to group the variables, (a) depth-SOM and (b) depth-pH. The results of the test between dependent (PTEs) and independent (depth and SOM) variables (Table 6) showed that soil depth accounts for significant variations between the group means: $\mathrm{Bi}(p=0.035), \mathrm{Cd}(p=0.015)$ and $\mathrm{W}(p=0.009)$. The independent variable SOM shows significant variations in the concentration of As $(p=0.021), \mathrm{Bi}$ $(p=0.068), \mathrm{W}(p=0.013)$ and $\mathrm{Zn}(p=0.021)$. There is no significant interaction between depth and SOM. While the independent variable $\mathrm{pH}$ (Table 7) shows that there are significant variations with depth for most PTEs (Ag $p=0.071$; As $p=0.027$; $\mathrm{Bi} p=0.001$; $\mathrm{Cd} p<0.000$; $\mathrm{W} p<0.000)$, except for $\mathrm{Cu}(p=0.371) . \mathrm{pH}$ presents a significant variation for $\mathrm{Ag}(p=0.031), \mathrm{W}(p=0.001)$ and $\mathrm{Zn}$ $(p<0.001)$. The interaction between $\mathrm{pH}^{*}$ depth shows no significant variations $(p>0.050)$, except on the concentration of $\mathrm{Cu}(p=0.038)$.

\subsection{Quantitative Assessment of Soil Contamination}

In this study, a simplified approach to assess soil contamination based on comparing the measured concentrations in the Panasqueira soil with the geochemical background values for Casegas was adopted. Table 8 shows the results of contamination factors $(C F)$ and the modified degree of contamination $\left(m C_{d}\right)$ for the selected elements in topsoil and subsoil, and also in Casegas soil. 
Table 6. Two-way ANOVA results between the dependent (PTEs) and independent (depth, $\mathrm{SOM}$ ) variables. PTEs were subjected to log-normal transformation (As, $\mathrm{As}, \mathrm{Cd}, \mathrm{Cu}, \mathrm{W}$ and $\mathrm{Zn}$ with $\alpha=0.050$; Bi with $\alpha=0.075$ ).

\begin{tabular}{|c|c|c|c|c|c|}
\hline Source of Variation & Dependent Variables & $\mathrm{d} f$ & Mean Square & $\boldsymbol{F}$ & $p$-Value \\
\hline \multirow{7}{*}{ Depth } & Ag & 1 & 0.223 & 1.624 & 0.204 \\
\hline & As & 1 & 0.127 & 1.652 & 0.200 \\
\hline & $\mathbf{B i}$ & 1 & 0.333 & 4.484 & 0.035 \\
\hline & Cd & 1 & 0.926 & 5.951 & 0.015 \\
\hline & $\mathrm{Cu}$ & 1 & 0.012 & 0.483 & 0.488 \\
\hline & $\mathbf{W}$ & 1 & 1.486 & 6.928 & 0.009 \\
\hline & $\mathbf{Z n}$ & 1 & 0.062 & 1.933 & 0.166 \\
\hline \multirow{7}{*}{ SOM } & Ag & 1 & 0.010 & 0.076 & 0.783 \\
\hline & As & 1 & 0.417 & 5.422 & 0.021 \\
\hline & $\mathbf{B i}$ & 1 & 0.251 & 3.371 & 0.068 \\
\hline & Cd & 1 & 0.160 & 1.029 & 0.311 \\
\hline & $\mathbf{C u}$ & 1 & 0.007 & 0.275 & 0.601 \\
\hline & $\mathbf{W}$ & 1 & 1.763 & 8.219 & 0.005 \\
\hline & $\mathbf{Z n}$ & 1 & 0.173 & 5.372 & 0.021 \\
\hline \multirow{7}{*}{ Depth*SOM } & Ag & 1 & 0.051 & 0.373 & 0.542 \\
\hline & As & 1 & 0.007 & 0.093 & 0.760 \\
\hline & $\mathbf{B i}$ & 1 & 0.001 & 0.008 & 0.928 \\
\hline & $\mathrm{Cd}$ & 1 & 0.001 & 0.006 & 0.940 \\
\hline & $\mathrm{Cu}$ & 1 & 0.037 & 1.52 & 0.219 \\
\hline & $\mathbf{W}$ & 1 & 0.095 & 0.44 & 0.506 \\
\hline & Zn & 1 & 0.002 & 0.06 & 0.811 \\
\hline \multirow{7}{*}{ Error } & Ag & 238 & 0.137 & - & - \\
\hline & As & 215 & 0.077 & - & - \\
\hline & $\mathbf{B i}$ & 225 & 0.074 & - & - \\
\hline & Cd & 233 & 0.156 & - & - \\
\hline & $\mathrm{Cu}$ & 218 & 0.024 & - & - \\
\hline & $\mathbf{W}$ & 215 & 0.215 & - & - \\
\hline & $\mathrm{Zn}$ & 235 & 0.032 & - & - \\
\hline
\end{tabular}

According the topsoil median values of the contamination factor, $\mathrm{Bi}, \mathrm{Cd}$ and $\mathrm{W}$ present an extremely high degree of contamination, while Ag and As a high contamination factor. The results demonstrated that $m C_{d}$ values vary from the minimum 1.2 in both topsoil and subsoil to the maximum of 150 in topsoil, with median values varying from 4 in subsoil to 6 in topsoil. The cumulative frequency distribution indicates that only $7.4 \%$ of the soil samples were classified as no to low degree of pollution, with $m C_{d}$ values $<2.0$, and the remaining soil samples $(92.6 \%)$ registered moderate to ultra-high degree of pollution, with $m C_{d}$ values equal or greater than $2.0\left(27.9 \%\right.$ between $2 \leq m C_{d}<4 ; 27.1 \%$ between $4 \leq m C_{d}<8 ; 19.7 \%$ between $8 \leq m C_{d}<16 ; 15.6 \%$ between $16 \leq m C_{d}<32$ and $2.5 \%$ between $32 \leq m C_{d}$ ). The enrichment is more pronounced in topsoil (subsoil $m C_{d}$ values ranged 1.2-26.4). 
Table 7. Two-way ANOVA results between the dependent (PTEs) and independent (depth, $\mathrm{pH}$ ) variables. PTEs were subjected to log-normal transformation (As, $\mathrm{Bi}, \mathrm{Cd}, \mathrm{Cu}, \mathrm{W}, \mathrm{Zn}$ with $\alpha=0.050$; Ag with $\alpha=0.075$ ).

\begin{tabular}{|c|c|c|c|c|c|}
\hline Source of Variation & Dependent Variables & $\mathrm{d} f$ & Mean Square & $\boldsymbol{F}$ & $p$-Value \\
\hline \multirow{7}{*}{ Depth } & Ag & 1 & 0.353 & 3.296 & 0.071 \\
\hline & As & 1 & 0.512 & 4.930 & 0.027 \\
\hline & $\mathbf{B i}$ & 1 & 0.832 & 10.605 & 0.001 \\
\hline & Cd & 1 & 1.810 & 13.449 & 0.000 \\
\hline & $\mathrm{Cu}$ & 1 & 0.019 & 0.805 & 0.371 \\
\hline & $\mathbf{W}$ & 1 & 3.055 & 14.560 & 0.000 \\
\hline & Zn & 1 & 0.007 & 0.266 & 0.607 \\
\hline \multirow{7}{*}{ pH } & Ag & 1 & 0.506 & 4.726 & 0.031 \\
\hline & As & 1 & 0.031 & 0.301 & 0.584 \\
\hline & $\mathbf{B i}$ & 1 & 0.017 & 0.222 & 0.638 \\
\hline & Cd & 1 & 0.020 & 0.146 & 0.703 \\
\hline & $\mathrm{Cu}$ & 1 & 0.000 & 0.001 & 0.971 \\
\hline & $\mathbf{W}$ & 1 & 2.315 & 11.033 & 0.001 \\
\hline & Zn & 2 & 0.605 & 21.777 & 0.000 \\
\hline \multirow{7}{*}{ Depth*pH } & Ag & 1 & 0.116 & 1.085 & 0.299 \\
\hline & As & 1 & 0.053 & 0.510 & 0.476 \\
\hline & $\mathbf{B i}$ & 1 & 0.082 & 1.040 & 0.309 \\
\hline & Cd & 1 & 0.179 & 1.332 & 0.250 \\
\hline & $\mathrm{Cu}$ & 1 & 0.104 & 4.351 & 0.038 \\
\hline & $\mathbf{W}$ & 1 & 0.321 & 1.532 & 0.217 \\
\hline & Zn & 2 & 0.077 & 2.769 & 0.065 \\
\hline \multirow{7}{*}{ Error } & Ag & 233 & 0.107 & - & - \\
\hline & As & 230 & 0.104 & - & - \\
\hline & $\mathbf{B i}$ & 225 & 0.078 & - & - \\
\hline & Cd & 226 & 0.135 & - & - \\
\hline & $\mathrm{Cu}$ & 217 & 0.024 & - & - \\
\hline & $\mathbf{W}$ & 213 & 0.210 & - & - \\
\hline & $\mathbf{Z n}$ & 233 & 0.028 & - & - \\
\hline
\end{tabular}

Table 8. Contamination Factors $(C F)$ and Modified Degree of Contamination $\left(m C_{d}\right)$ using geochemical background values. Casegas area is considered as representative of geochemical background.

\begin{tabular}{|c|c|c|c|c|c|c|c|c|c|}
\hline \multicolumn{2}{|c|}{ Var } & $\mathbf{A g}_{C F}$ & $\mathbf{A} \mathbf{s}_{C F}$ & $\mathbf{B i}_{C F}$ & $\mathbf{C} \mathbf{d}_{C F}$ & $\mathbf{C} \mathbf{u}_{C F}$ & $\mathbf{W}_{C F}$ & $\mathbf{Z} \mathbf{n}_{C F}$ & $m C_{d}$ \\
\hline \multirow{3}{*}{ Bk } & Min & 1.0 & 0.4 & 0.7 & 1.0 & 0.6 & 0.1 & 0.3 & 0.7 \\
\hline & Med & 1.0 & 1.0 & 1.0 & 1.0 & 1.0 & 1.1 & 1.0 & 1.4 \\
\hline & Max & 8 & 5 & 9 & 30 & 6 & 26 & 2 & 13 \\
\hline \multirow{3}{*}{ Topsoil } & Min & 1.0 & 0.8 & 1.0 & 5.0 & 0.4 & 0.6 & 0.4 & 1.2 \\
\hline & Med & 2 & 3 & 3 & 20 & 1.2 & 17 & 1.2 & 6 \\
\hline & Max & 34 & 68 & 215 & 300 & 10 & 571 & 3 & 150 \\
\hline \multirow{3}{*}{ Subsoil } & Min & 1.0 & 0.4 & 0.7 & 5.0 & 0.4 & 0.1 & 0.3 & 1.2 \\
\hline & Med & 2 & 2 & 2 & 10 & 1.1 & 8 & 1.2 & 4 \\
\hline & Max & 12 & 16 & 51 & 150 & 5 & 84 & 3 & 26 \\
\hline
\end{tabular}


Casegas is considered as an uncontaminated site, since it is outside the mine area and the influence of airborne polluted dust. The maximum $m C_{d}$ value of 13.1 , represents a very high contamination degree, which is mostly due to the $\mathrm{Cd}$ and $\mathrm{W}$ contamination factors. In this case, however, the high $m C_{d}$ value is most likely due to geogenic sources, as this is a naturally enriched and mineralized zone.

The calculated $m C_{d}$ values make possible the assessment of the spatial distribution of the modified degree of contamination. The first step is the determination of the spatial structure of the new variables, and the experimental variograms were used to model the data using exponential models, the extracted parameters are for topsoil: main direction $=90^{\circ}$; Nugget effect $\left(C_{0}\right)=30$; Sill-Nugget effect $\left(C_{1}\right)=330$; range of influence (length) $=1200 \mathrm{~m}$; anisotropy ratio $=1.81$; and for subsoil: main direction $=90^{\circ} ; C_{0}=0 ; C_{1}=19 ;$ length $=900 \mathrm{~m}$; anisotropy ratio $=2.90$. Estimation of the spatial distribution was then achieved by Ordinary Kriging and the respective map plotted. In Figure 5 it is possible to observe the $m C_{d}$ spatial distribution revealing areas with very high values.

Figure 5 shows that soil samples collected near the Barroca Grande tailings (A), Rio tailings (C) and the mud impoundments stand out clearly, because the soil is enriched in $\mathrm{Ag}, \mathrm{As}, \mathrm{Bi}, \mathrm{Cd}, \mathrm{Cu}, \mathrm{W}$ and $\mathrm{Zn}$; all soil samples from both depths taken from Barroca Grande exceed the As, Bi, Cd and W baseline values for Portugal, while at Rio only $\mathrm{Zn}$ in some samples (25\%) has concentrations that are lower than the guide value. According to [42], the Barroca Grande tailings and open impoundments have high $\mathrm{As}, \mathrm{Cd}, \mathrm{Cu}, \mathrm{Pb}, \mathrm{W}$, and $\mathrm{Zn}$ concentrations (mean content in the more coarse tailings material $\mathrm{As}=7142 \mathrm{mg} \cdot \mathrm{kg}^{-1} ; \mathrm{Cd}=56 \mathrm{mg} \cdot \mathrm{kg}^{-1} ; \mathrm{Cu}=2501 \mathrm{mg} \cdot \mathrm{kg}^{-1} ; \mathrm{Pb}=172 \mathrm{mg} \cdot \mathrm{kg}^{-1} ; \mathrm{Sn}=679 \mathrm{mg} \cdot \mathrm{kg}^{-1}$; $\mathrm{W}=5400 \mathrm{mg} \cdot \mathrm{kg}^{-1}$ and $\mathrm{Zn}=1689 \mathrm{mg} \cdot \mathrm{kg}^{-1}$ and mean content in the impoundment material (rejected from the mill operations) $\mathrm{As}=44,252 \mathrm{mg} \cdot \mathrm{kg}^{-1} ; \mathrm{Cd}=491 \mathrm{mg} \cdot \mathrm{kg}^{-1} ; \mathrm{Cu}=4029 \mathrm{mg} \cdot \mathrm{kg}^{-1} ; \mathrm{Pb}=166 \mathrm{mg} \cdot \mathrm{kg}^{-1}$; $\mathrm{Sn}=454 \mathrm{mg} \cdot \mathrm{kg}^{-1} ; \mathrm{W}=3380 \mathrm{mg} \cdot \mathrm{kg}^{-1}$ and $\mathrm{Zn}=3738 \mathrm{mg} \cdot \mathrm{kg}^{-1}$ ). The mineralogy of these tailings consists of mainly quartz, muscovite, kaolinite, illite-montmorillonite, montmorillonite-vermiculite, and chlorite, and also arsenopyrite, wolframite, and natrojarosite.

Figure 5. Spatial distribution of the modified degree of Contamination $\left(m C_{d}\right)$ for topsoil (a) and subsoil (b). Values were estimated on the basis of the concentration factors of $\mathrm{Ag}, \mathrm{As}$, Bi, Cd, Cu, W and Zn (A, Barroca Grande; B, S. Francisco de Assis; C, Rio).

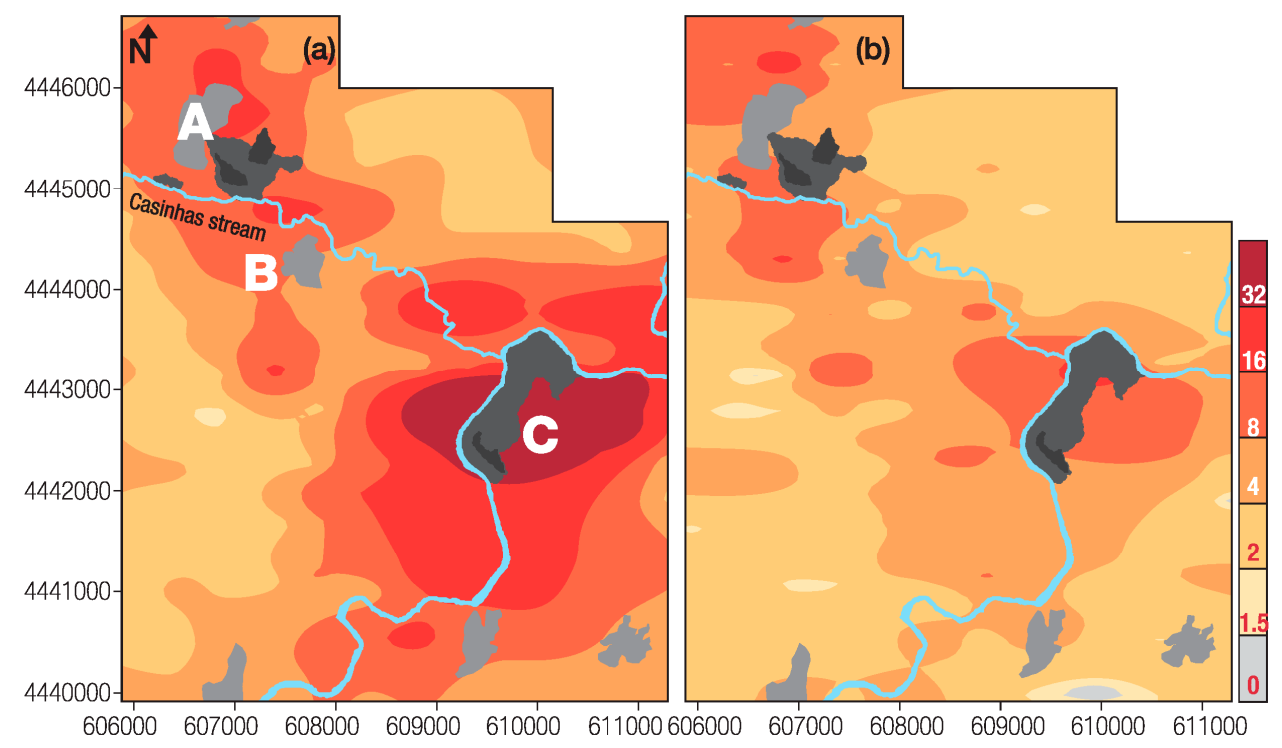


The dams at Barroca Grande may pose a significant potential threat, due to the fine-grained nature of the materials, and their location with respect to the Casinhas stream that cross S. Francisco de Assis village. The X-Ray Diffraction (XRD) analysis of the impoundment material revealed the presence of scorodite, arsenopyrite, quartz, sphalerite, hematite, and muscovite. These tailings and impoundment material are metal-enriched at such a level, likely to be toxic to the ecosystem [42]. The concentrations exceed the values defined for the 90th percentile of the South Portuguese Zone (As $157 \mathrm{mg} \cdot \mathrm{kg}^{-1}$; $\mathrm{Cu} 108 \mathrm{mg} \cdot \mathrm{kg}^{-1}$; Ni $62 \mathrm{mg} \cdot \mathrm{kg}^{-1}$; Pb $117 \mathrm{mg} \cdot \mathrm{kg}^{-1} ; \mathrm{Zn} 134 \mathrm{mg} \cdot \mathrm{kg}^{-1}$ ), which is indicative of enrichment in trace metals. This Ag-As-Bi-Cd-Cu-W-Zn association is quite logical and is linked to the Panasqueira ore-paragenetic association. The highest $m C_{d}$ values identified near Barroca Grande (A), São Francisco de Assis (B) and Rio (C) confirms that mechanical and chemical dispersion from Barroca Grande and Rio tailings and mud impoundments occurs. Most of the samples $(90 \%$ or higher of total samples) collected from Barroca Grande (A), São Francisco de Assis (B) and Rio (C) villages, exhibit $m C_{d}$ values $>8.0$, clearly indicting a very high degree of contamination.

The Panasqueira tailings impoundments have been and are affected by surface water flows (from heavy rainfall events) that have eroded the tailings from their original location and transported the materials downstream to residential areas (namely to S. Francisco de Assis). However, the superficial flat of the tailings have dried and are susceptible to wind erosion. The relative rates of water and wind erosion and transport, in Barroca Grande, São Francisco de Assis and Rio, suggest that wind processes have similar, and in many cases greater, impact on loss and local redistribution of soil in ecosystems than an eventual erosional soil enrichment.

\subsection{Potential Ecological Risk Factor and Risk Index}

The topsoil and subsoil samples results for individual element potential pollution factor $(E F)$ and potential ecological risk (PERI) are presented in Table 9. For both soil sample depths, As, $\mathrm{Cu}$ and $\mathrm{Zn}$ show a low potential ecological risk, with median values $<40$ (see Table 2). Tungsten also exhibits a low risk in subsoil, but a high risk in topsoil, while Bi and Ag show a moderate risk at both depths. Cadmium presents a very high ecological risk in topsoil and a high risk on subsoil. Using the median values, the topsoil risk factor is ranked as: $\mathrm{Cd}>\mathrm{W}>\mathrm{Ag}>\mathrm{Bi}>\mathrm{As}>>\mathrm{Cu}>\mathrm{Zn}$, while for subsoil the ranking is: $\mathrm{Cd}>\mathrm{Ag}>\mathrm{Bi}>\mathrm{As}>\mathrm{Cu}=\mathrm{W}>\mathrm{Zn}$. These results suggest a very high environmental risk, especially for $\mathrm{Cd}$.

In order to estimate the global potential ecological risk in the study area, the PERI was computed. The median values classify soil samples at both depths with a very high risk (Table 9). The cumulative analysis shows that the soil samples at both depths do not display a low risk index $(<150)$, and only $7.4 \%$ of topsoil present a moderate risk index. PERI classified $92.6 \%$ of topsoil samples as high to very high ecological risk. The same occurs for $61.2 \%$ of subsoil samples, which should be considered as an extensive hazard. Figure 6 displays the PERI spatial distribution. Topsoil has a wide area classified with a very high ecological risk, which is consistent with the wind direction, the water courses and the actual and previous exploration and beneficiation locations (Figure 6a). Subsoil also presents a very high risk index in the same topsoil areas, but with smaller area expression. These results are consistent with those mapped by the individual elements, $\mathrm{Ag}, \mathrm{As}, \mathrm{Bi}, \mathrm{Cd}, \mathrm{Cu}, \mathrm{W}$ and $\mathrm{Zn}$ (Figures $2-4)$, and the modified degree of contamination $\left(m C_{d}\right.$; Figure 5), with the same affected areas. 
Table 9. Statistical results of the single element potential pollution factor $(E F)$ and potential ecological risk (PERI) for topsoil and subsoil samples.

\begin{tabular}{|c|c|c|c|c|c|c|c|c|c|}
\hline Va & & $\mathbf{A g}_{E F}$ & $\mathbf{A} \mathbf{s}_{E F}$ & $\mathbf{B} \mathbf{i}_{E F}$ & $\mathbf{C} \mathbf{d}_{E F}$ & $\mathbf{C} \mathbf{u}_{E F}$ & $\mathbf{W}_{E F}$ & $\mathbf{Z} \mathbf{n}_{E F}$ & PERI \\
\hline \multirow{4}{*}{ Topsoil } & Min & 120 & 4 & 20 & 150 & 1 & 9 & 0 & 224 \\
\hline & Mean & 120 & 23 & 127 & 893 & 3 & 573 & 1 & 1,740 \\
\hline & Med & 70 & 15 & 60 & 600 & 2 & 255 & 1 & 1,020 \\
\hline & Max & 1,190 & 338 & 4,300 & 9,000 & 21 & 8,571 & 3 & 23,353 \\
\hline \multirow{4}{*}{ Subsoil } & Min & 30 & 4 & 10 & 125 & 2 & 2 & 0 & 173 \\
\hline & Mean & 76 & 33 & 56 & 418 & 7 & 8 & 1 & 600 \\
\hline & Med & 60 & 23 & 30 & 250 & 6 & 6 & 1 & 350 \\
\hline & Max & 360 & 158 & 770 & 3,750 & 26 & 203 & 3 & 4,369 \\
\hline
\end{tabular}

Figure 6. Spatial distribution of Potential Ecological Risk Index (PERI) for topsoil (a) and subsoil (b) in the study area.

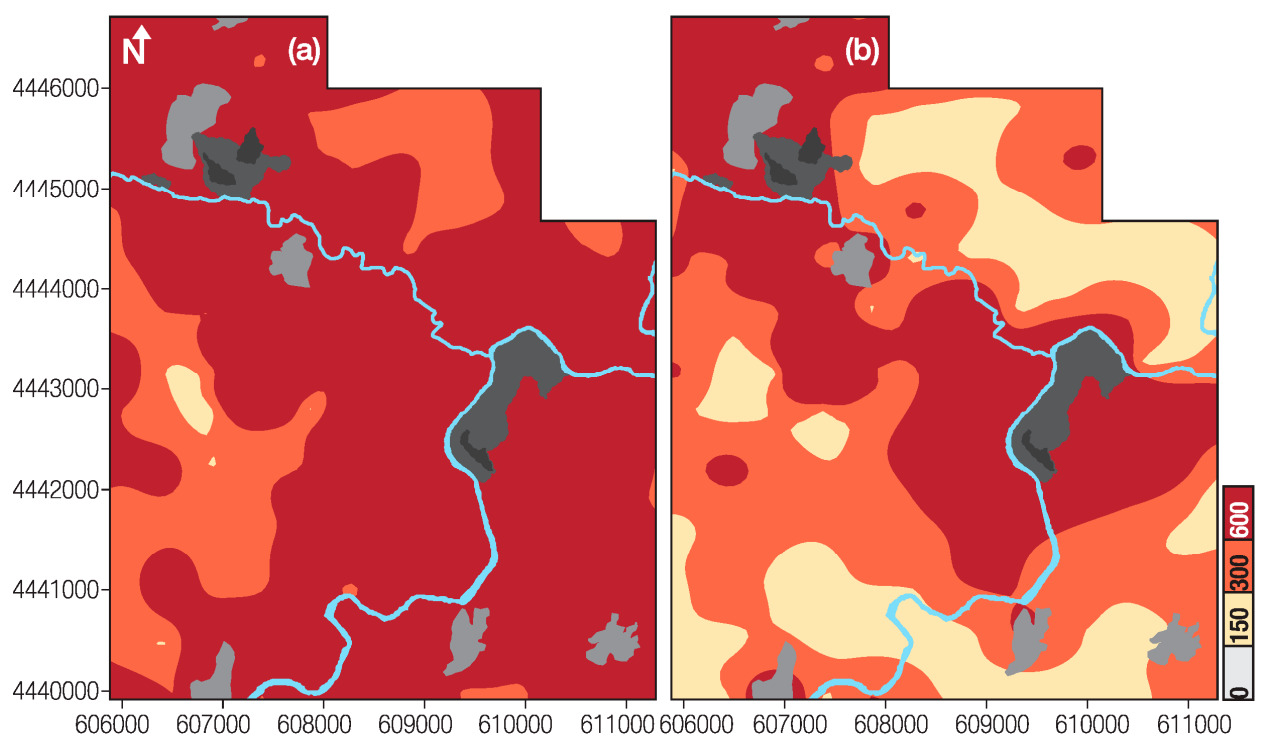

\subsection{Human Health Risk Assessment}

Both non-carcinogenic hazard $(H Q)$ and carcinogenic risk (Riskpathway) of topsoil in the Panasqueira mine and surrounding area, through the different pathways (ingestion, dermal and inhalation), were estimated according to the human health risk assessment model [28]. The cumulative hazard index $(H I)$ and total risk (Risktotal) were also characterized for multi-pathway routes in resident population.

The non-carcinogenic effects considered the most conservative exposure condition-children (1-6 years old). The potentially toxic elements defined in this study ( $\mathrm{Ag}, \mathrm{Cd}, \mathrm{Cu}, \mathrm{W}$ and $\mathrm{Zn}$ ), apart from As, do not present a non-carcinogenic hazard for children in the Panasqueira area (maximum $H I_{\text {child-Ag, } \mathrm{Cd}, \mathrm{Cu}, \mathrm{W}, \mathrm{Zn}} \leq 0.37$ ). The As non-carcinogenic hazard median values, estimated for the different exposure routes were $H Q_{\text {ing-As }}(2.75)>H Q_{\text {drm-As }}(0.23) \gg P Q_{\text {inh-As }}(0.00) . H I_{\text {child-As }}$ values ranged between 0.78 and 69.50 , with a median value of $2.98 \approx H Q_{\text {ing-As }}(2.70)$, due to the ingestion hazard quotient ranging between 0.72 and 64.10. These results $(<1-$ safe level) indicate that there is a cause for concern for the non-cancer health effects for children living in the Panasqueira study area, mainly due to As oral ingestion, with $H Q_{\text {ing-As }}$ showing median values above one (Figure 7). 
Figure 7. Comparative boxplot distribution of the Non-carcinogenic Hazard Quotient for children of As for Ingestion ( $H Q_{\text {ingAs }}$ ), Inhalation ( $\left.H Q_{\mathrm{ihnAs}}\right)$, Dermal contact $\left(H Q_{\mathrm{drmAs}}\right)$ routes, the Cumulative Hazard Index $\left(H I_{\mathrm{As}}\right)$ and the sum of the Non-carcinogenic Hazard Quotient of the other defined PTEs $(\mathrm{Ag}, \mathrm{Cd}, \mathrm{Cu}, \mathrm{W}$ and $\mathrm{Zn})$ for Ingestion $\left(H Q_{\mathrm{ingPTE}(-\mathrm{As})}\right)$, Inhalation $\left(H Q_{\text {ihnPTE(-As) }}\right)$, Dermal contact $\left(H Q_{\text {drmPTE}}(-\mathrm{As})\right)$ routes and the Cumulative Hazard Index $\left(H I_{\mathrm{PTE}(-\mathrm{As})}\right)$ for topsoil samples (tailing samples were removed) in the Panasqueira area. The extremes and outliers were removed.

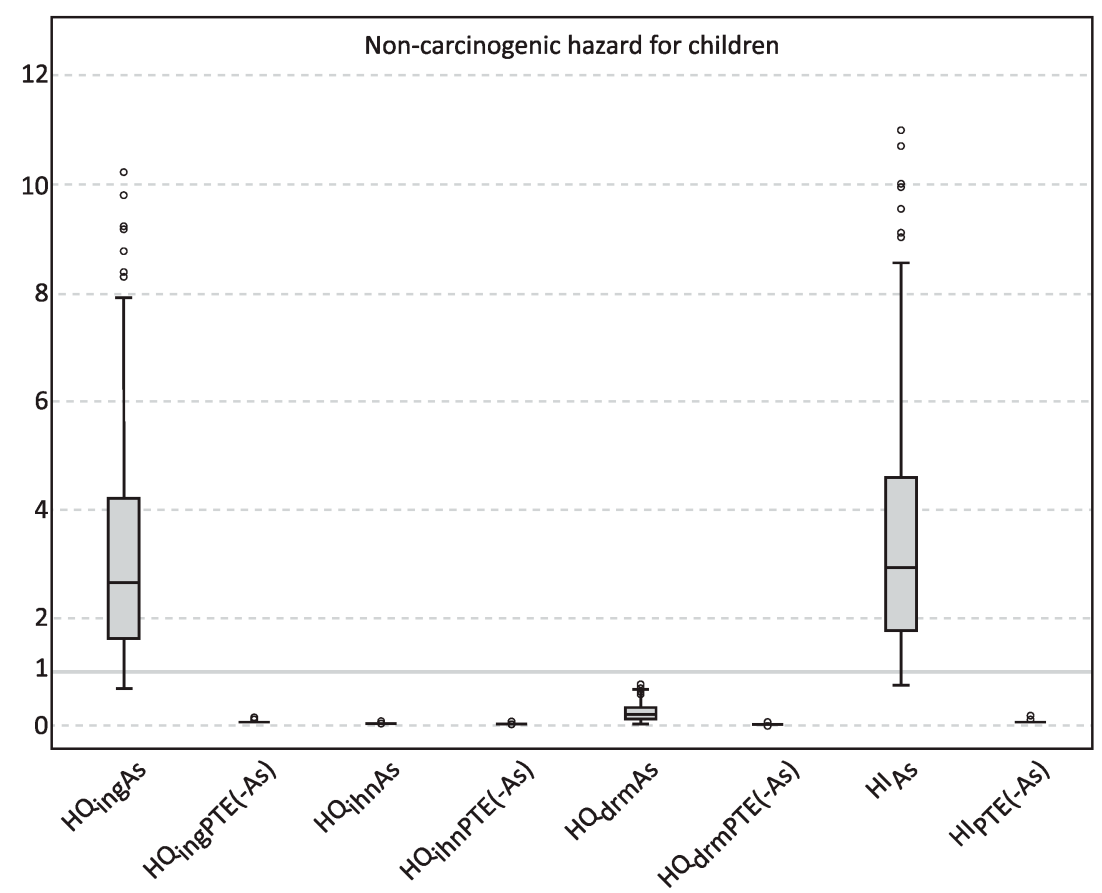

The carcinogenic risks adjusted both to children and adult were studied for the identified PTEs in this study. The median values of the different exposure routes and total risk were estimated. Their mean distribution were Risk total $\left(2.62 \times 10^{-4}\right) \approx \operatorname{Risk}_{\text {As }}\left(2.62 \times 10^{-4}\right) \approx \operatorname{Risk}_{\text {ing }}\left(2.39 \times 10^{-4}\right) \approx$ RiskingAs $_{\text {is }}$

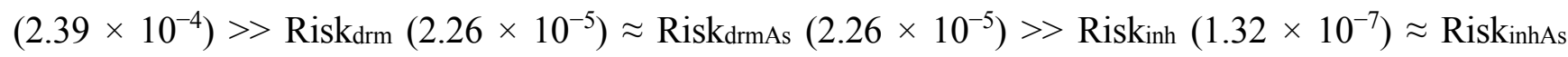
$\left(1.32 \times 10^{-7}\right)$ (Figure 8$)$. The high significance of As to cumulative carcinogenic elements risk is due to the very low risk displayed by the other elements. Furthermore, the representation of the exposure

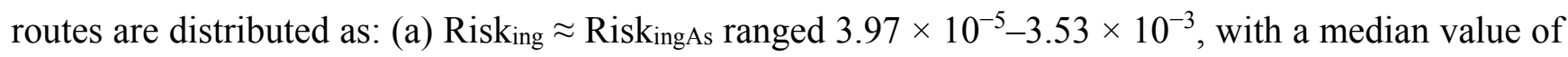
$1.52 \times 10^{-4}$; (b) Risk drm $_{2} \approx$ Risk $_{\text {drmAs }}$ ranged $3.76 \times 10^{-6}-3.34 \times 10^{-4}$, with median value of $1.44 \times 10^{-5}$; and (c) Riskinh $\approx$ RiskinhAs ranged $2.21 \times 10^{-8}-1.96 \times 10^{-6}$, with median value of $8.38 \times 10^{-8}$. The cumulative pathway Risk total $_{2} \approx$ Risk $_{\text {As }}$ ranged $4.35 \times 10^{-5}-3.87 \times 10^{-3}$, with a median Risktotal of $1.66 \times 10^{-4}$ mostly due to RiskingAs. Intake of As may cause cancer in several human organs through ingestion, and lung and skin cancer through inhalation [28]. Moreover, the Risking represents 91.29\% of cumulative risk from exposure routes, while Riskdrm $(8.69 \%)$ and Riskinh $(0.05 \%)$ have less significance. Similar results were obtained in other studies [77,91-94]. The cumulative median Riskdrm is $>1 \times 10^{-6}$ for all samples, of which $69.67 \%>1 \times 10^{-5}$, and the cumulative exposure route median Risking is $>1 \times 10^{-5}$ for all samples, being $72.13 \%>1 \times 10^{-4}$. These results show that there is a very high As ingestion cancer risk. The samples with higher hazard are located in and around the villages of the study area, being the more representative results found nearby the large tailing piles and open air 
impoundments (Figure 9). Although the median Riskdrm value is lower and between $1 \times 10^{-6}$ and $1 \times 10^{-4}$, and is considered as acceptable, it cannot, however, be negligible in the Panasqueira mining area, once all samples exceed the target value $\left(1 \times 10^{-6}\right)$. While the sum of exposure pathways is Riskcd $=1.09 \times 10^{-10}$ $\left(<1 \times 10^{-6}\right)$, it should be noted that it is the cumulative toxic metal and kidney index that is the main target for Cd toxicity [26,95].

Figure 8. Comparative boxplot distribution of the Carcinogenic Risk adjusted to both children and adult for total PTEs ( $\mathrm{Ag}, \mathrm{As}, \mathrm{Cd}, \mathrm{Cu}, \mathrm{W}$ and $\mathrm{Zn}$ ) for Ingestion (Risking), Inhalation (Riskinh), Dermal contact (Riskdrm) routes, the Cumulative Risk (Risk total) and the Carcinogenic Risk of As for Ingestion (RiskingAs), Inhalation (RiskinhAs), Dermal (RiskdrmAs) routes and the Cumulative Risk (RiskAs) for topsoil samples (tailing samples were removed) of the Panasqueira area. The extremes and outliers were removed.

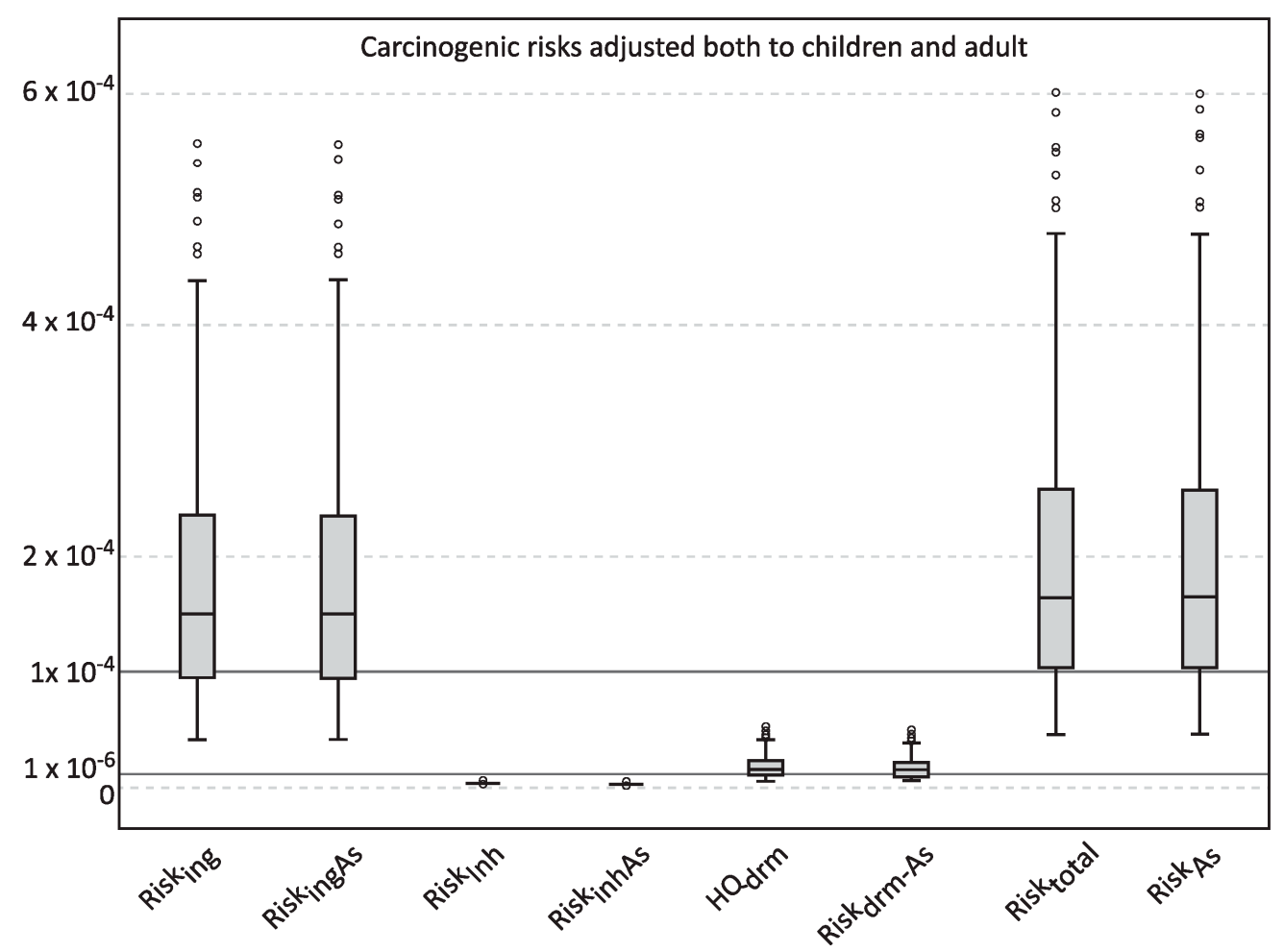

As the risk analyses showed that ingestion is the most important pathway, further studies should be carried out in order to estimate the metal bioaccessibility in human receptors, such as a simplified in vitro physiologically based extraction test (PBET), allowing the estimation of the percentage of the bioaccessible orally ingested fraction of each metal from soil samples [77,80,96]. Additional investigations must be made on different sample media, such as vegetables, rhizosphere, irrigation and drinking water and street dust in the local villages under influence of mining activities (such as S. Francisco de Assis and Barroca) and also in non-exposed villages considered as reference areas (such as Casegas and Unhais-o-Velho). These studies will provide the necessary data and information for the determination of the influence of the Panasqueira mine activities, through more than 110 years, on the surrounding population, and should be complemented by biological studies [97]. 
Figure 9. Spatial distribution of the Carcinogenic risk adjusted for both children and adult considering (a) ingestion; (b) dermal contact; (c) inhalation routes; and (d) the cumulative Risk.

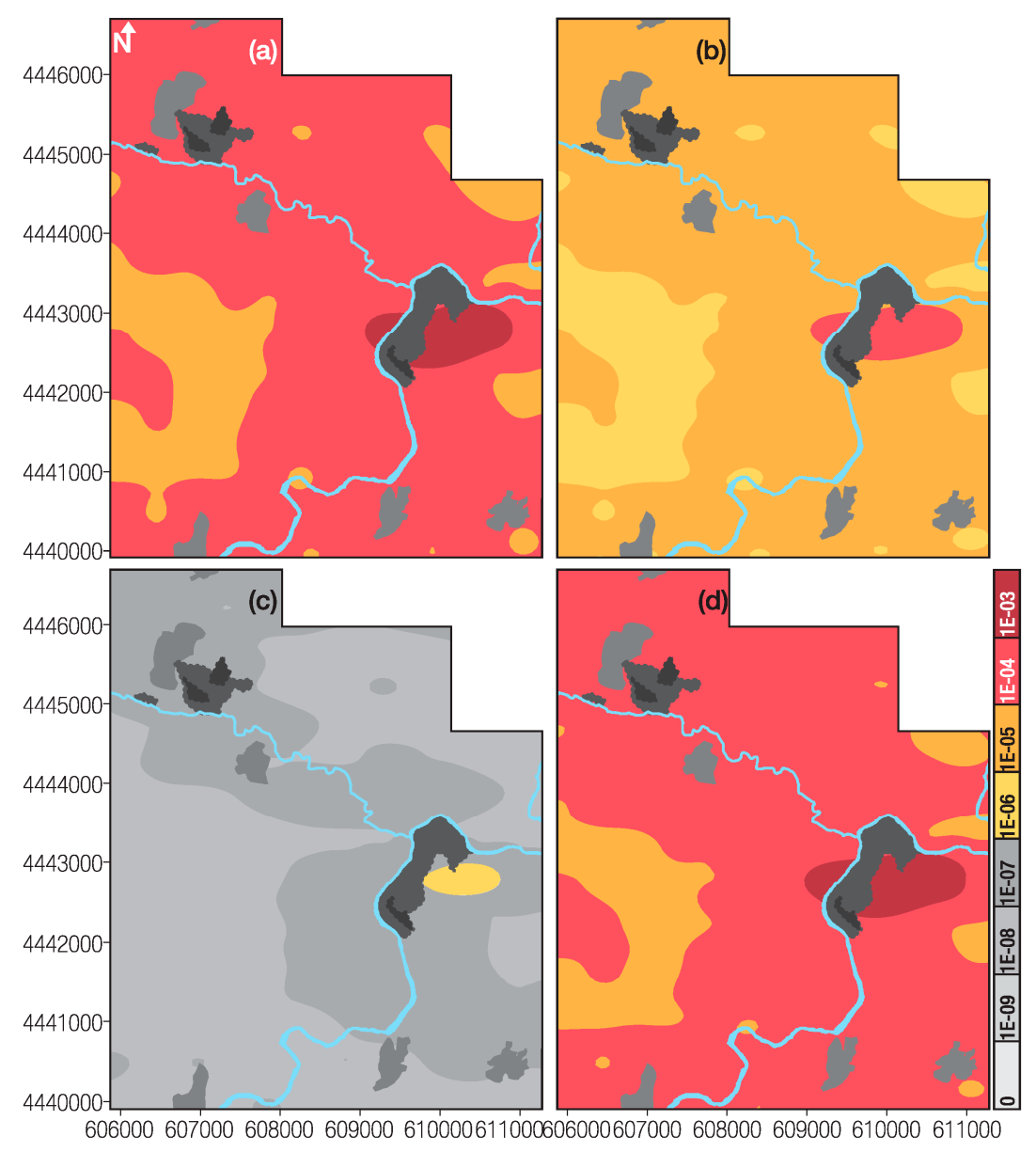

\section{Conclusions}

The mining and beneficiation process generates huge quantities of waste materials from the ore extraction and milling operations, which accumulate in tailings and open impoundments and are largely responsible for the high levels of metals(loid)s released into the surrounding environment. At the Panasqueira mine, the mining activities have produced sulphide-rich mine wastes that are responsible for the high levels of metals at Barroca Grande and Rio tailings. The oxidation of these sulphides may give rise to the mobilization and migration of trace metals from the mining wastes into the soil. Heavy metal soil contamination is an outstanding example of environmental risk. Metal(loid)s, such as $\mathrm{As}, \mathrm{Cd}$ or $\mathrm{Pb}$, for example, are toxic for humans, as well as for animals, and can even lead to death if ingested in large doses, or over large periods of time. Exposure to hazardous elements may have different pathways, such as ingestion, dermal absorption and inhalation of soil particles present in the air.

Collection of surface soil permits the characterization of anthropogenic contamination, caused by the presence of tailings and open air impoundments. Such soil, classified globally as very acid to acid, occurs in areas with very low soil $\mathrm{pH}$ values, which are related to areas with the highest SOM values. The metal assemblage identified in these soil types ( $\mathrm{Ag}, \mathrm{As}, \mathrm{Bi}, \mathrm{Cd}, \mathrm{Cu}, \mathrm{W}$ and $\mathrm{Zn}$ ) show highest 
values in topsoil samples $(0-15 \mathrm{~cm})$, when compared with the values of the corresponding subsoil samples below $15 \mathrm{~cm}$ depth. Soil samples from both depths have higher contents when compared to the estimated local geochemical background. These results show the influence of the metal-rich mine wastes, stored in Barroca Grande and Rio tailings and in the open impoundments, as the main source of pollution of the surrounding environment, possibly due to aerial transport and deposition.

Very strong correlations were estimated between the PTEs and between PTEs and $\mathrm{pH}$. The strongest correlations were $\mathrm{Ag} / \mathrm{Cu}, \mathrm{As} / \mathrm{Ag}$ and $\mathrm{Bi} / \mathrm{W}$. The PTEs and $\mathrm{pH}$ positive correlation, confirm the findings of other studies that heavy metal mobility holds a positive correlation with $\mathrm{pH}$, affecting their availability.

The ANOVA results, showed significant variations with depth, and the majority of the PTEs (Ag, $\mathrm{As}, \mathrm{Bi}, \mathrm{Cd}$ and $\mathrm{W}$ ) and $\mathrm{pH}$ exhibit a significant variation for $\mathrm{Ag}, \mathrm{W}$ and $\mathrm{Zn}$.

According to the calculated contamination factor $(C F)$ and the modified degree of contamination $\left(m C_{d}\right), 7.4 \%$ of the soil samples were classified as having no to low degree of pollution with $m C_{d}<2.0$ and $92.6 \%$ registered moderate to ultra-high degree of pollution with $m C_{d} \geq 2.0$. The spatial distribution of the $m C_{d}$ reveals areas with a very high degree of contamination. The highest $m C_{d}$ values were identified near Barroca Grande, São Francisco de Assis and Rio, and confirm the mechanical and chemical dispersion from tailings.

The risk factor estimated for individual element potential pollution factor and potential ecological risk, revealed at both soil sample depths that $\mathrm{As}, \mathrm{Cu}$ and $\mathrm{Zn}$ have a low potential ecological risk, $\mathrm{W}$ low risk in subsoil, but a very high risk in topsoil samples; Ag moderate to considerable ecological risk and $\mathrm{Cd}$ is the worst element, exhibiting a very high environmental risk. The estimated potential ecological risk (PERI) classifies samples from both depths with a very high risk. In the PERI spatial distribution, topsoil has a wide area classified with a very high ecological risk, consistent with wind direction, water courses and current and previous exploration and beneficiation locations.

The non-carcinogenic hazard effects, determined for children (1-6 years old), indicated that the PTEs ( $\mathrm{Ag}, \mathrm{Cd}, \mathrm{Cu}, \mathrm{W}$ and $\mathrm{Zn}$ ) do not present a non-carcinogenic hazard for children, while the As value is high, representing a risk for the non-cancer health effects for children in the Panasqueira area. The carcinogenic risk for both children and adults, revealed a very high cancer risk due to As ingestion, which may cause cancer to several human organs cancer through ingestion, and lung and skin cancer through inhalation.

Further studies should be carried out in order to estimate the metal bioaccessibility in human receptors.

\section{Acknowledgments}

This research is financially supported by FCT_Fundação para a Ciência e a Tecnologia (grants SFRH/BD/63349/2009).

\section{Author Contributions}

The original idea of the study was designed on a brainstorm meeting by all authors. E. Ferreira da Silva and J. P. Teixeira were responsible for recruitment and follow-up of study participants. All authors participated on the field work. C. Candeias and P. F. Ávila were responsible for data cleaning and 
analyses. C. Candeias drafted the manuscript with collaboration of all authors and it was revised by all. All authors read and approved the final manuscript.

\section{Conflicts of Interest}

The authors declare no conflict of interests.

\section{References}

1. Cohen, R.R.H.; Gorman, J. Mining-related nonpoint-source pollution. Water Environ. Technol. 1991, 3, 55-59.

2. Merson, J. Mining with microbes. N. Sci. 1992, 133, 9-17.

3. Evangelou, V.P.B.; Zhang, Y.L. A review: Pyrite oxidation mechanisms and acid mine drainage prevention. Crit. Rev. Environ. Sci. Technol. 1995, 25, 141-199.

4. Larocque, A.C.L.; Rasmussen, P.E. An overview of trace metals in the environment, from mobilization to remediation. Environ. Geol. 1998, 33, 85-91.

5. Soucek, D.J.; Cherry, D.S.; Currie, R.J. Laboratory to field validation in an integrative assessment of an acid mine drainage-impacted watershed. Environ. Toxicol. Chem. 2000, 19, 1036-1043.

6. Candeias, C. Modelling the Impact of Panasqueira Mine in the Ecosystems and Human Health: A Multidisciplinar Approach. Ph.D. Thesis, Aveiro University/Porto University, Aveiro, Portugal, 2013.

7. Rasmussen, P.E. Long-range atmospheric transport of trace metals: The need for geosciences perspectives. Environ. Geol. 1998, 33, 96-108.

8. Yukselen, M.A.; Alpaslan, B. Leaching of metals from soil contaminated by mining activities. J. Hazard Mater. 2001, 87, 289-300.

9. Chen, X.; Wright, J.V.; Conca, J.L.; Peurrung, L.M. Evaluation of heavy metal remediation using mineral apatite. Water Air Soil Pollut. 1997, 98, 57-78.

10. Bosso, S.T.; Enzweiler, J. Bioaccessible lead in soils, slag, and mine wastes from an abandoned mining district in Brazil. Environ. Geochem. Health 2008, 30, 219-229.

11. Douay, F.; Pruvot, C.; Roussel, H.; Ciesielski, H.; Fourrier, H.; Proix, N.; Waterlot, C. Contamination of urban soils in an area of Northern France polluted by dust emissions of two smelters. Water Air Soil Pollut. 2008, 188, 247-260.

12. Roussel, H.; Waterlot, C.; Pelfrêne, A.; Pruvot, C.; Mazzuca, M.; Douay, F. Cd, Pb and Zn Oral Bioaccessibility of urban soils contaminated in the past by atmospheric emissions from two lead and zinc smelters. Arch. Environ. Contam. Toxicol. 2010, 58, 945-954.

13. Juhasz, A.L.; Weber, J.; Smith, E. Impact of soil particle size and bioaccessibility on children and adult lead. J. Hazard Mater. 2011, 186, 1870-1879.

14. Ettler, V.; Kribek, B.; Majer, V.; Knesl, I.; Mihaljevic, I. Differences in the bioaccessibility of metals/metalloids in soils from mining smelting areas (Copperbelt, Zambia). J. Geochem. Explor. 2012, 113, 68-75.

15. Banza, C.L.N.; Nawrot, T.S.; Haufroid, V.; Decre, S.; de Putter, T.; Smolders, E.; Kabyla, B.I.; Luboya, O.N.; Ilunga, A.N.; Mutombo, A.M.; et al. High human exposure to cobalt and other metals in Katanga, a mining area of the Democratic Republic of Congo. Environ. Res. 2009, 109, 745-752. 
16. Radojevic, M.; Bashki, V.N. Practical Environmental Analysis; The Royal Society of Chemistry: Cambridge, UK, 2006.

17. Krishnamurti, G.S.R.; Huang, P.M.; Kozak, L.M. Sorption and desorption kinetics of cadmium from soils: Influence of phosphate. Soil Sci. 1999, 164, 888-898.

18. Antoniadis, V.; Robinson, J.S.; Alloway, B.J. Effects of short-term $\mathrm{pH}$ fluctuations on cadmium, nickel, lead, and zinc availability to ryegrass in a sewage sludge-amended field. Chemosphere 2008, 71, 759-764.

19. Mühlbachová, G.; Simon, T.; Pechová, M. The availability of $\mathrm{Cd}, \mathrm{Pb}$ and $\mathrm{Zn}$ and their relationships with soil $\mathrm{pH}$ and microbial biomass in soils amended by natural clinoptilolite. Plant Soil Environ. 2005, 51, 26-33.

20. Zhao, K.L.; Liu, X.M.; Xu, J.M.; Selim, H.M. Heavy metal contaminations in a soil-rice system: Identification of spatial dependence in relation to soil properties of paddy fields. J. Hazard Mater. 2010, 181, 778-787.

21. Zeng, F.; Ali, S.; Zhang, H.; Ouyang, Y.; Qiu, B.; Wu, F.; Zhang, G. The influence of pH and organic matter content in paddy soil on heavy metal availability and their uptake by rice plants. Environ. Pollut. 2011, 159, 84-91.

22. Sukreeyapongse, O.; Holme, P.E.; Strobel, B.W.; Panichsakpatana, S.; Magid, J.; Hansen, H.C.B. $\mathrm{pH}$-dependent release of cadmium, copper, and lead from natural and sludge-amended soils. J. Environ. Qual. 2002, 31, 1901-1909.

23. Oliver, D.P.; Tiller, K.G.; Connyers, M.K.; Sattery, W.J.; Alston, A.M.; Merry, R.H. Effectiveness of liming to minimise uptake of cadmium by wheat and barley grain grown in the field. Aust. J. Agric. Res. 1996, 47, 1181-1193.

24. Braillier, S.; Harrison, R.B.; Hennry, C.L.; Dogsen, X. Liming effects on availability of Cd, Cu, $\mathrm{Ni}$ and $\mathrm{Zn}$ in a soil amended with sewage sludge 16 years previously. Water Air Soil Pollut. 2006, 86, 195-206.

25. Du Laing, G.; Vanthuyne, D.R.J.; Vandecasteele, B.; Tack, F.M.G.; Verloo, M.G. Influence of hydrological regime on pore water metal concentrations in a contaminated sediment-derived soil. Environ. Pollut. 2007, 147, 615-625.

26. Zheng, N.; Liu, J.; Wang, Q.; Liang, Z. Health risk assessment of heavy metal exposure to street dust in the zinc smelting district, Northeast of China. Sci. Total Environ. 2010, 408, 726-733.

27. Mudgal, V.; Madaan, N.; Mudgal, A.; Singh, R.B.; Mishra, S. Effect of toxic metals on human health. Open Nutraceuticals J. 2010, 3, 94-99.

28. U.S. Department of Energy. The Risk Assessment Information System (RAIS); U.S. Department of Energy's Oak Ridge Operations Office (ORO): Oak Ridge, TN, USA, 2013.

29. Agency for Toxic Substances and Disease Registry. Available online: http://www.atsdr.cdc.gov/ (accessed on 23 September 2014).

30. World Health Organization (WHO). Monographs-Analytical and Toxicological Data. In Basic Analytical Toxicology; World Health Organization: Geneva, Switzerland, 2013.

31. National Drug Formulary of Ethiopia; Drug Administration and Control Authority of Ethiopia (DACAE): Addis Ababa, Ethiopia, 2007. 
32. Candeias, C.; Ferreira da Silva, E.; Ávila, P.F.; Salgueiro, A.R.; Teixeira, J.P. Integrated approach to assess the environmental impact of mining activities: Multivariate statistical analysis to estimate the spatial distribution of soil contamination in the Panasqueira mining area (Central Portugal). Environ. Monit. Assess. 2014, in press.

33. Smith, M. Panasqueira the tungsten giant at 100+. Oper. Focus. Int. Min. 2006, 33, 10-14.

34. Thadeu, D. Geologia do couto mineiro da Panasqueira. Comunicações dos Serviços Geológicos de Portugal 1951, 32, 5-64. (In Portuguese)

35. Bloot, C.; de Wolf, L.C.M. Geological features of the Panasqueira tin-tungsten ore occurrence (Portugal). Bol. Soc. Geol. Port. 1953, 11, 1-58.

36. Kelly, W.C.; Rye, R.O. Geologic, fluid inclusion and stable isotope studies of the tin-tungsten deposits of Panasqueira, Portugal. Econ. Geol. 1979, 74, 1721-1822.

37. Polya, D.A. Chemistry of the main stage ore-forming fluids of the Panasqueira W-Cu(Ag)-Sn deposit, Portugal: Implications for models of ore genesis. Econ. Geol. 1989, 84, 1134-1152.

38. Noronha, F.; Dória, A.; Dubessy, J.; Charoy, B. Characterisation and timing of the different types of fluids present in the barren and ore-veins of the W-Sn deposit of Panasqueira, Central Portugal. Miner. Deposita 1992, 27, 72-79.

39. Correia, A.; Naique, R.A. Minas Panasqueira, 100 Years of Mining History. In Proceedings of the International Tungsten Industrial Association (ITIA) Conference, Salzburg, Austria, 20-22 October 1998.

40. Corrêa de Sá, A.; Naique, R.A.; Nobre, E. Minas da Panasqueira: 100 anos de História. Bol. Minas 1999, 36, 3-22. (In Portuguese)

41. e-Ecorisk, A Regional Enterprise Network Decision-Support System for Environmental Risk and Disaster Management of Large-Scale Industrial Soils, Contract n. ${ }^{\circ}$ EGV1-CT-2002-00068; WP3-Case Study Site Characterization, Project Management Report for the Reporting Period, Deliverable 3.1; Joanneum Research Forschungsgeselfschaft-GMBH: Frohnleiten, Austria, 2007; not published.

42. Ávila, P.; Ferreira da Silva, E.; Salgueiro, A.; Farinha, J.A. Geochemistry and Mineralogy of Mill Tailings Impoundments from the Panasqueira Mine (Portugal): Implications for the Surrounding Environment. Mine Water Environ. 2008, 27, 210-224.

43. Ferreira da Silva, E.; Ávila, P.F.; Salgueiro, A.R.; Candeias, C.; Pereira, H.G. Quantitative-spatial assessment of soil contamination in S. Francisco de Assis due to mining activity of the Panasqueira mine (Portugal). Environ. Sci. Pollut. Res. 2013, 20, 7534-7549.

44. Candeias, C.; Melo, R.; Ávila, P.F.; Ferreira da Silva, E.; Salgueiro, A.R.; Teixeira, J.P. Heavy metal pollution in mine-soil-plant system in S. Francisco de Assis-Panasqueira mine (Portugal). Appl. Geochem. 2014, 44, 12-26.

45. Jaques Ribeiro, L.M.; Gonçalves, A.C.R. Contributo para o conhecimento geológico e geomorfológico da área envolvente do Couto Mineiro da Panasqueira. Centro de Estudos de Geografia e Ordenamento do Território. Revista de Geografia e Ordenamento do Território 2013, 3, 93-116. (In Portuguese)

46. Atlas do Potencial Eólico para Portugal Continental, Version 1.0 [CD-ROM]; ISBN 972-676-196-4; Instituto Nacional de Engenharia, Tecnologia e Inovação I.P. (INETI): Lisboa, Portugal, 2004. (In Portuguese) 
47. Reis, A.C. As Minas da Panasqueira. Bol. Minas 1971, 8, 3-34. (In Portuguese)

48. Costa, P.; Estanqueiro, A. Development and Validation of the Portuguese Wind Atlas. In Proceedings of the European Wind Energy Conference, Athens, Greece, 27 February-2 March 2006.

49. Costa, P.; Estanqueiro, A. Building a Wind Atlas for Mainland Portugal Using a Weather Type Classification. In Proceedings of the European Wind Energy Conference, Athens, Greece, 27 February-2 March 2006.

50. Costa, P.A.S. Atlas do Potencial eólico para Portugal Continental. Master's Thesis, University of Lisbon, Lisboa, Portugal, 2004. (In Portuguese)

51. Turner, A.P. The responses of plants to heavy metals. In Toxic Metals in Soil-Plant Systems; Sheila, M.R., Ed.; John Wiley \& Sons: Hoboken, NJ, USA, 1994.

52. Mcbride, M.B.; Richards, B.; Steenhuis, T.; Russo, J.J.; Sauvé, S. Mobility and solubility of toxic metals and nutrients in soil fifteen years after sludge application. Soil Sci. 1997, 162, 487-500.

53. Van Reeuwijk, L.P. Procedures for Soil Analysis, 6th ed.; International Soil Reference and Information Centre: Wageningen, The Netherlands, 2002.

54. ISO 10390:1994 Soil; In Soil Quality-Determination of $p H$; International Organization for Standardization: Geneva, Switzerland, 1995.

55. Schnitzer, M.; Khan, S.U. Substances in the Environment; Marcel Dekker: New York, NY, USA, 1972.

56. Stevenson, F.J. Humus Chemistry; Wiley: New York, NY, USA, 1982.

57. Yin, Y.; Allen, H.E.; Huang, C.P.; Sparks, D.L.; Sanders, P.F. Kinetics of mercury (II): Adsorption and desorption on soil. Environ. Sci. Technol. 1997, 31, 496-503.

58. You, S.J.; Yin, Y.; Allen, H.E. Partitioning of organic matter in soils: Effects of pH and water soil ratio. Sci. Total Environ. 1999, 227, 155-160.

59. Zar, J.H. Biostatistical Analysis; Prentice Hall: New York, NY, USA, 1996.

60. Johnson, R.A.; Wichern, D.W. Applied Multivariate Statistical Analysis; Prentice-Hall: New York, NY, USA, 1998.

61. Corwin, D.L.; Lesh, S.M.; Oster, J.D.; Kaffka, S.R. Monitoring management-induced spatio-temporal changes in soil quality through soil sampling direct by apparent electrical conductivity. Geoderma 2006, 131, 369-387.

62. Hakanson, L. Ecological risk index for aquatic pollution control, a sedimentological approach. Water Res. 1980, 14, 975-1001.

63. Loska, K.; Wiechula, D.; Korus, I. Metal contamination of farming soils affected by industry. Environ. Int. 2004, 30, 159-165.

64. Liu, W.H.; Zhao, J.Z.; Ouyang, Z.Y.; Solderland, L.; Liu, G.H. Impacts of sewage irrigation on heavy metal distribution and contamination in Beijing, China. Environ. Int. 2005, 32, 805-812.

65. Tuckey, J.W. Exploratory Data Analysis; Addison Wesley: Boston, MA, USA, 1977.

66. Abrahim, G.M.S.; Parker, R.J. Assessment of heavy metal enrichment factors and the degree of contamination in marine sediments from Tamaki Estuary, Auckland, New Zealand. Environ. Monit. Assess. 2008, 136, 227-238.

67. Reimann, C.; Caritat, P. Chemical Elements in the Environment: Factsheets for the Geochemist and Environmental Scientist; Springer: Berlin, Germany, 1998.

68. Bowen, H.J.M. Trace Elements in Biochemistry; Academic Press: London, UK, 1966. 
69. U.S. Environmental Protection Agency (USEPA). Risk Assessment Guidance for Superfund, Volume I: Human Health Evaluation Manual; EPA 540-1-89-002; U.S. Environmental Protection Agency: Washington, DC, USA, 1989.

70. U.S. Environmental Protection Agency (USEPA). Soil Screening Guidance: Technical Background Document; EPA 540-R-95-128; U.S. Environmental Protection Agency: Washington, DC, USA, 1996.

71. Linders, J.B.H.J. Risicobeoordelino voor de mens bij blootstelling aan stoffen: Uitgangspunten en veronderstellingen. In Rapport/Rijksinstituut voor Volksgezondheid en Milieuhygiene (nr. 725201003); RIVM: Bilthoven, The Netherlands, 1990. (In Dutch)

72. Berg, R.V.D. Human Exposure to Soil Contamination: A Qualitative and Quantitative Analysis towards Proposals for Human Toxicological Intervention Values (Partly Revised Edition); Report No. 725201011; National Institute for Public Health and the Environment: Bilthoven, The Netherlands, 1994.

73. U.S. Environmental Protection Agency (USEPA). Risk Assessment Guidance for Superfund: Volume III-Part A, Process for Conducting Probabilistic Risk Assessment; EPA 540-R-02-002; U.S. Environmental Protection Agency: Washington, DC, USA, 2001.

74. U.S. Environmental Protection Agency (USEPA). Integrated Risk Information System (IRIS); U.S. Environmental Protection Agency: Washington, DC, USA, 2013.

75. INE. Portal do Instituto Nacional de Estatística-Statistics Portugal. Available online: http://www.ine.pt/ (accessed on 23 September 2014). (In Portuguese)

76. U.S. Environmental Protection Agency (USEPA). Guidance for Evaluating the Oral Bioavailability of Metals in Soils for Use in Human Health Risk Assessment; OSWER 9285.7-80; U.S. Environmental Protection Agency: Washington, DC, USA, 2007.

77. Luo, X.S.; Ding, J.; Xu, B.; Wang, Y.J.; Li, H.B.; Yu, S. Incorporating bioaccessibility into human health risk assessments of heavy metals in urban park soils. Sci. Total Environ. 2012, 424, $88-96$.

78. Hu, X.; Zhang, Y.; Luo, J.; Wang, T.; Lian, H.; Ding, Z. Bioaccessibility and health risk of arsenic, mercury and other metals in urban street dusts from a mega-city, Nanjing, China. Environ. Pollut. 2011, 159, 1215-1221.

79. U.S. Environmental Protection Agency (USEPA). Screening Levels (RSL) for Chemical Contaminants at Superfund Sites; U.S. Environmental Protection Agency: Washington, DC, USA, 2013.

80. Luo, X.S.; Yu, S.; Li, X.D. The mobility, bioavailability, and human bioaccessibility of trace metals in urban soils of Hong Kong. Appl. Geochem. 2012, 27, 995-1004.

81. U.S. Department of Agriculture. Available online: http://www.nrcs.usda.gov (accessed on 23 September 2014).

82. Tidball, R.R.; Ebens, R.J. Regional geochemical baselines in soils of the Powder River Basin, Montana-Wyoming. In Geology and Energy Resources of the Powder River; 28th Annual Field Conference Guidebook; American Association of Petroleum Geologists (AAPG): Tulsa, OK, USA, 1976.

83. Ministry of the Environment. Soil, Ground Water and Sediment Standards for the Use under Part XV.1 of the Environmental Protection Act; Ministry of the Environment: Ottawa, Canada, 2011. 
84. Fiedler, H.J.; Rösler, H.J. Spurenelemente in der Umwelt; Gustav Fischer Verlag: Jena, Germany, 2013. (In German)

85. Mench, M. Notions sur les éléments en traces pour une qualité des sols et des produits végétaux. Purpan 1993, 166, 118-127. (In French)

86. Deschamps, E.; Ciminelli, V.S.T.; Lange, F.T.; Matschullat, J.; Raue, B.; Schmidt, H. Soil and sediment geochemistry of the iron quadrangle, Brazil: The case of arsenic. J. Soils Sediment. 2002, 2, 216-222.

87. Ferreira, M.M.S.I. Dados Geoquímicos de Base de Solos de Portugal Continental, Utilizando Amostragem de Baixa Densidade. Ph.D. Thesis, University of Aveiro, Aveiro, Portugal, 2004. (In Portuguese)

88. Yuan, G.; Lavkulich, L.M. Sorption behavior of copper, zinc, and cadmium in response to simulated changes in soil properties. Commun. Soil Sci. Plant Anal. 1997, 28, 571-587.

89. Hettiarachchi, G.M.; Ryan, J.A.; Chaney, R.L.; La Fleur, C.M. Sorption and desorption of cadmium by different fractions of biosolids-amended soils. J. Environ. Qual. 2003, 32, 1684-1693.

90. Qishlaqi, A.; Moore, F. Statistical analysis of accumulation and sources of heavy metals occurrence in agricultural soils of Khoshk River Banks, Shiraz, Iran. J. Agric. Environ. Sci. 2007, 2, 565-573.

91. Chabukdhara, M.; Nema, A.K. Heavy metals assessment in urban soil around insutrial clusters in Ghaziabad, India: Probabilistic health risk approach. Ecotoxicol. Environ. Saf. 2013, 87, 57-64.

92. De Miguel, E.; Iribarren, I.; Chacón, E.; Ordoñez, A.; Charlesworth, S. Risk-based evaluation of the exposure of children to trace elements in playgrounds in Madrid (Spain). Chemosphere 2007, 66, 505-513.

93. Ferreira-Baptista, L.; de Miguel, E. Geochemistry and risk assessment of street dust in Luanda, Angola: A tropical urban environment. Atmos. Environ. 2005, 39, 4501-4512.

94. Dudka, S.; Miller, W.P. Permissible concentrations of arsenic and lead in soils based on risk assessment. Water Air Soil Pollut. 1999, 113, 127-132.

95. De Burbure, C.; Buchet, J.P.; Bernard, A.; Leroyer, A.; Nisse, C.; Haguenoer, J.M.; Bergamaschi, E.; Mutti, A. Biomarkers of renal effects in children and adults with low environmental exposure to heavy metals. J. Toxicol. Environ. Health 2003, 66, 783-798.

96. Drexler, J.W.; Brattin, W.J. An in vitro procedure for estimation of lead relative bioavailability: With validation. Hum. Ecol. Risk Assess. 2007, 13, 383-401.

97. Coelho, P.; Costa, S.; Costa, C.; Silva, S.; Walter, A.; Ranville, J.; Pastorinho, R.; Harrington, C.; Taylor, A.; Dall'Armi, V.; et al. Biomonitoring of several toxic metal(loid)s in different biological matrices from environmentally and occupationally exposed populations from Panasqueira mine area, Portugal. Environ. Geochem. Health 2013, 36, 255-269.

(C) 2014 by the authors; licensee MDPI, Basel, Switzerland. This article is an open access article distributed under the terms and conditions of the Creative Commons Attribution license (http://creativecommons.org/licenses/by/4.0/). 